\title{
Seasonal variations of triple oxygen isotopic compositions of atmospheric sulfate, nitrate, and ozone at Dumont d'Urville, coastal Antarctica
}

\author{
Sakiko Ishino $^{1}$, Shohei Hattori ${ }^{1}$, Joel Savarino ${ }^{2}$, Bruno Jourdain ${ }^{2}$, Susanne Preunkert ${ }^{2}$, Michel Legrand ${ }^{2}$, \\ Nicolas Caillon $^{2}$, Albane Barbero ${ }^{2}$, Kota Kuribayashi ${ }^{3}$, and Naohiro Yoshida ${ }^{1,4}$ \\ ${ }^{1}$ Department of Chemical Science and Engineering, School of Materials and Chemical Technology, \\ Tokyo Institute of Technology, G1-17, 4259 Nagatsuta-cho, Midori-ku, Yokohama 226-8502, Japan \\ ${ }^{2}$ IGE, Univ. Grenoble Alpes, CNRS, IRD, INP-G, 38000 Grenoble, France \\ ${ }^{3}$ Department of Environmental Chemistry and Engineering, Tokyo Institute of Technology, \\ 4259 Nagatsuta-cho, Midori-ku, Yokohama 226-8502, Japan \\ ${ }^{4}$ Earth-Life Science Institute, Tokyo Institute of Technology, Meguro-ku, Tokyo 152-8551, Japan
}

Correspondence to: Sakiko Ishino (ishino.s.ab@m.titech.ac.jp)

Received: 18 October 2016 - Discussion started: 24 October 2016

Revised: 22 February 2017 - Accepted: 22 February 2017 - Published: 16 March 2017

\begin{abstract}
Triple oxygen isotopic compositions $\left(\Delta^{17} \mathrm{O}=\right.$ $\left.\delta^{17} \mathrm{O}-0.52 \times \delta^{18} \mathrm{O}\right)$ of atmospheric sulfate $\left(\mathrm{SO}_{4}^{2-}\right)$ and nitrate $\left(\mathrm{NO}_{3}^{-}\right)$in the atmosphere reflect the relative contribution of oxidation pathways involved in their formation processes, which potentially provides information to reveal missing reactions in atmospheric chemistry models. However, there remain many theoretical assumptions for the controlling factors of $\Delta^{17} \mathrm{O}\left(\mathrm{SO}_{4}^{2-}\right)$ and $\Delta^{17} \mathrm{O}\left(\mathrm{NO}_{3}^{-}\right)$values in those model estimations. To test one of those assumption that $\Delta^{17} \mathrm{O}$ values of ozone $\left(\mathrm{O}_{3}\right)$ have a flat value and do not influence the seasonality of $\Delta^{17} \mathrm{O}\left(\mathrm{SO}_{4}^{2-}\right)$ and $\Delta^{17} \mathrm{O}\left(\mathrm{NO}_{3}^{-}\right)$values, we performed the first simultaneous measurement of $\Delta^{17} \mathrm{O}$ values of atmospheric sulfate, nitrate, and ozone collected at Dumont d'Urville (DDU) Station $\left(66^{\circ} 40^{\prime} \mathrm{S}, 140^{\circ} 01^{\prime} \mathrm{E}\right)$ throughout 2011. $\Delta^{17} \mathrm{O}$ values of sulfate and nitrate exhibited seasonal variation characterized by minima in the austral summer and maxima in winter, within the ranges of $0.9-3.4$ and $23.0-41.9 \%$, respectively. In contrast, $\Delta{ }^{17} \mathrm{O}$ values of ozone showed no significant seasonal variation, with values of $26 \pm 1 \%$ o throughout the year. These contrasting seasonal trends suggest that seasonality in $\Delta^{17} \mathrm{O}\left(\mathrm{SO}_{4}^{2-}\right)$ and $\Delta^{17} \mathrm{O}\left(\mathrm{NO}_{3}^{-}\right)$values is not the result of changes in $\Delta^{17} \mathrm{O}\left(\mathrm{O}_{3}\right)$, but of the changes in oxidation chemistry. The trends with summer minima and winter maxima for $\Delta^{17} \mathrm{O}\left(\mathrm{SO}_{4}^{2-}\right)$ and $\Delta^{17} \mathrm{O}\left(\mathrm{NO}_{3}^{-}\right)$values
\end{abstract}

are caused by sunlight-driven changes in the relative contribution of $\mathrm{O}_{3}$ oxidation to the oxidation by $\mathrm{HO}_{x}, \mathrm{RO}_{x}$, and $\mathrm{H}_{2} \mathrm{O}_{2}$. In addition to that general trend, by comparing $\Delta^{17} \mathrm{O}\left(\mathrm{SO}_{4}^{2-}\right)$ and $\Delta^{17} \mathrm{O}\left(\mathrm{NO}_{3}^{-}\right)$values to ozone mixing ratios, we found that $\Delta^{17} \mathrm{O}\left(\mathrm{SO}_{4}^{2-}\right)$ values observed in spring (September to November) were lower than in fall (March to May), while there was no significant spring and fall difference in $\Delta^{17} \mathrm{O}\left(\mathrm{NO}_{3}^{-}\right)$values. The relatively lower sensitivity of $\Delta^{17} \mathrm{O}\left(\mathrm{SO}_{4}^{2-}\right)$ values to the ozone mixing ratio in spring compared to fall is possibly explained by (i) the increased contribution of $\mathrm{SO}_{2}$ oxidations by $\mathrm{OH}$ and $\mathrm{H}_{2} \mathrm{O}_{2}$ caused by $\mathrm{NO}_{x}$ emission from snowpack and/or (ii) $\mathrm{SO}_{2}$ oxidation by hypohalous acids $(\mathrm{HOX}=\mathrm{HOCl}+\mathrm{HOBr})$ in the aqueous phase.

\section{Introduction}

Triple oxygen isotopic compositions $\left(\Delta^{17} \mathrm{O}=\right.$ $\left.\delta^{17} \mathrm{O}-0.52 \times \delta^{18} \mathrm{O}\right)$ of atmospheric sulfate and nitrate have shown the potential to probe the relative importance of various oxidation pathways involved in their formations (e.g., Michalski et al., 2003; Lee and Thiemens, 2001). Atmospheric ozone $\left(\mathrm{O}_{3}\right)$ possesses high $\Delta^{17} \mathrm{O}$ values of approximately $26 \%$ (Krankowsky et al., 1995; Johnston and 
Thiemens, 1997; Vicars et al., 2012; Vicars and Savarino, 2014), in contrast to most of the oxygen bearing compounds such as $\mathrm{O}_{2}$ and $\mathrm{H}_{2} \mathrm{O}$ which have $\Delta^{17} \mathrm{O}$ values of approximately 0\%o (Barkan and Luz, 2003, 2005). The oxygen atoms of $\mathrm{O}_{3}$ are directly or indirectly transferred to sulfate and nitrate through the various oxidation pathways of their precursors, $\mathrm{SO}_{2}$ and $\mathrm{NO}_{x}\left(=\mathrm{NO}+\mathrm{NO}_{2}\right)$ respectively. Therefore, $\mathrm{O}_{3}$ oxidation produces sulfate and nitrate possessing high $\Delta^{17} \mathrm{O}$ values, whereas oxidation by $\mathrm{OH}, \mathrm{RO}_{2}$, and $\mathrm{H}_{2} \mathrm{O}_{2}$ produces sulfate and nitrate with low $\Delta^{17} \mathrm{O}$ values. In general, the $\Delta^{17} \mathrm{O}\left(\mathrm{SO}_{4}^{2-}\right)$ and $\Delta^{17} \mathrm{O}\left(\mathrm{NO}_{3}^{-}\right)$ values can be prognosticated using the given $\Delta^{17} \mathrm{O}\left(\mathrm{SO}_{4}^{2-}\right)$ and $\Delta^{17} \mathrm{O}\left(\mathrm{NO}_{3}^{-}\right)$values for each reaction pathway and the estimates of relative contribution of each oxidation pathways by atmospheric chemistry transport models (e.g., Alexander et al., 2009; Morin et al., 2011; Sofen et al., 2011). Considering the higher $\mathrm{HO}_{x}$ levels in summer due to enhanced photochemical activity relative to winter, $\Delta^{17} \mathrm{O}\left(\mathrm{SO}_{4}^{2-}\right)$ and $\Delta^{17} \mathrm{O}\left(\mathrm{NO}_{3}^{-}\right)$values are expected to show the specific seasonal trend with summer minima and winter maxima in the mid- to high-latitude regions. By comparing those expected values to observations, the missing processes for sulfate and nitrate formation in the models have been proposed. For example, McCabe et al. (2006) performed a year-round observation of $\Delta^{17} \mathrm{O}\left(\mathrm{SO}_{4}^{2-}\right)$ values at Alert, Canada, showing lower $\Delta^{17} \mathrm{O}\left(\mathrm{SO}_{4}^{2-}\right)$ values during winter compared to the calculated values using a model from Feitcher et al. (1996); McCabe et al. (2006) suggested a 2-fold overestimate of $\mathrm{O}_{3}$ oxidation in sulfate formation during winter in the Northern Hemisphere and pointed out a $10-18 \%$ contribution of metal-catalyzed $\mathrm{O}_{2}$ oxidation in aqueous phase. An observation of $\Delta^{17} \mathrm{O}\left(\mathrm{NO}_{3}^{-}\right)$values in Alert by Morin et al. (2008) revealed significantly higher values during spring compared to the calculated values, which is expected to be a result of $\mathrm{NO}_{2}$ oxidation by $\mathrm{BrO}$. Savarino et al. (2013) also had shown significantly higher $\Delta^{17} \mathrm{O}\left(\mathrm{NO}_{3}^{-}\right)$values at the marine boundary layer compared to an estimate of the chemical transport model by Alexander et al. (2009), while the mismatch was fixed by considering a contribution of $\mathrm{BrO}$ in nitrate formation. The $\Delta^{17} \mathrm{O}\left(\mathrm{SO}_{4}^{2-}\right)$ and $\Delta^{17} \mathrm{O}\left(\mathrm{NO}_{3}^{-}\right)$values are thus used to examine the lack of oxidation schemes in the models. However, the observational data of $\Delta^{17} \mathrm{O}\left(\mathrm{SO}_{4}^{2-}\right)$ and $\Delta^{17} \mathrm{O}\left(\mathrm{NO}_{3}^{-}\right)$to constrain these models are still not enough to demonstrate the theoretical assumptions of the controlling factors of $\Delta^{17} \mathrm{O}$ signatures in these model estimations (e.g., Morin et al., 2011).

One of the important parameters which have to be confirmed by observations is $\Delta^{17} \mathrm{O}$ value of ozone, because of the possibility that the $\Delta^{17} \mathrm{O}\left(\mathrm{SO}_{4}^{2-}\right)$ and $\Delta^{17} \mathrm{O}\left(\mathrm{NO}_{3}^{-}\right)$values are influenced not only by changes in oxidation chemistry but also variations in $\Delta^{17} \mathrm{O}\left(\mathrm{O}_{3}\right)$ values. Indeed, various $\Delta^{17} \mathrm{O}\left(\mathrm{O}_{3}\right)$ values ranging $25-35 \%$ are used for model calculations to reproduce the observed variations in $\Delta^{17} \mathrm{O}\left(\mathrm{SO}_{4}^{2-}\right)$ and $\Delta^{17} \mathrm{O}\left(\mathrm{NO}_{3}^{-}\right)$values (Alexander et al., 2009; Morin et al., 2011; Sofen et al., 2011). Those varied $\Delta^{17} \mathrm{O}\left(\mathrm{O}_{3}\right)$ values were assumed based on the observations using the cryogenic collection method (Johnston and Thiemens, 1997; Krankowsky et al., 1995), which showed highly varied values of 6-54\%o. However, the recent observations of $\Delta^{17} \mathrm{O}\left(\mathrm{O}_{3}\right)$ values using the nitrite-coated filter method - which was developed by Vicars et al. (2012) and applied at Grenoble, the R/V Polarstern Campaign (Vicars and Savarino, 2014), and Dome C (Savarino et al., 2016) - had shown the insignificant spatial and temporal variability with values ranging $23-$ $27 \%$. This result suggests that the variations observed in $\Delta^{17} \mathrm{O}\left(\mathrm{SO}_{4}^{2-}\right)$ and $\Delta^{17} \mathrm{O}\left(\mathrm{NO}_{3}^{-}\right)$values are not the result of changes in $\Delta^{17} \mathrm{O}\left(\mathrm{O}_{3}\right)$ values, but are mainly explained by the changes in oxidation pathways. To test this hypothesis, it is necessary to investigate the spatial and temporal variability of $\Delta{ }^{17} \mathrm{O}\left(\mathrm{O}_{3}\right)$ values, which is expected to have the stable value, simultaneously with variations in $\Delta^{17} \mathrm{O}\left(\mathrm{SO}_{4}^{2-}\right)$ and $\Delta^{17} \mathrm{O}\left(\mathrm{NO}_{3}^{-}\right)$values.

Antarctica is a suitable site to test this hypothesis because of the clear seasonality in solar radiation, which is one of the main factors influencing $\Delta^{17} \mathrm{O}\left(\mathrm{SO}_{4}^{2-}\right)$ and $\Delta^{17} \mathrm{O}\left(\mathrm{NO}_{3}^{-}\right)$ values through the changes in photochemical oxidant variations. In fact, several studies have reported the clear seasonal variations in $\Delta^{17} \mathrm{O}\left(\mathrm{NO}_{3}^{-}\right)$values at coastal and inland Antarctica, Dumont d'Urville (DDU) and Dome C, showing an austral summer minimum and a winter maximum (Erbland et al., 2013; Frey et al., 2009; Savarino et al., 2007). This trend is mainly explained by increased $\mathrm{NO}_{x}$ oxidation by $\mathrm{OH}$ and $\mathrm{RO}_{2}$ under solar radiation in summer relative to winter when $\mathrm{NO}_{x}$ oxidation is dominated by the reaction transferring the oxygen atoms from $\mathrm{O}_{3}$ to nitrate in dark polar winter, when assuming the values are mainly controlled by oxidation chemistry. The similar trend following the solar cycle is expected for $\Delta^{17} \mathrm{O}\left(\mathrm{SO}_{4}^{2-}\right)$ values, which is mainly controlled by the relative importance of $\mathrm{SO}_{2}$ oxidation by $\mathrm{OH}$, $\mathrm{H}_{2} \mathrm{O}_{2}$, and $\mathrm{O}_{3}$. The first attempt of the monthly scale observation of $\Delta^{17} \mathrm{O}\left(\mathrm{SO}_{4}^{2-}\right)$ values at Dome $\mathrm{C}$ showed the increasing trend from January to June (summer to winter) and the decreasing trend from October to next January (spring to summer) despite the unexpected decline during midwinter, July-August (Hill-Falkenthal et al., 2013). Nevertheless, the variability of $\Delta^{17} \mathrm{O}\left(\mathrm{SO}_{4}^{2-}\right)$ values throughout the year is larger than that which has ever been observed on earth (Lee and Thiemens, 2001; Li et al., 2013; McCabe et al., 2006). It is thus ideal to examine if the $\Delta{ }^{17} \mathrm{O}\left(\mathrm{O}_{3}\right)$ values show a flat value throughout the year in contrast to the seasonal variability in $\Delta^{17} \mathrm{O}\left(\mathrm{SO}_{4}^{2-}\right)$ and $\Delta^{17} \mathrm{O}\left(\mathrm{NO}_{3}^{-}\right)$values to demonstrate that the seasonality of $\Delta^{17} \mathrm{O}\left(\mathrm{SO}_{4}^{2-}\right)$ and $\Delta^{17} \mathrm{O}\left(\mathrm{NO}_{3}^{-}\right)$values is a direct consequence of changes in chemistry and not the variation in $\Delta{ }^{17} \mathrm{O}\left(\mathrm{O}_{3}\right)$ values at Antarctica.

In this study, we present the first simultaneous observations of $\Delta \Delta^{17} \mathrm{O}$ values of sulfate, nitrate, and ozone at the coastal Antarctic site, Dumont d'Urville Station throughout 2011, to answer the key question about the controlling factors 
of $\Delta^{17} \mathrm{O}\left(\mathrm{SO}_{4}^{2-}\right)$ and $\Delta^{17} \mathrm{O}\left(\mathrm{NO}_{3}^{-}\right)$values as well as to provide a set of data that can be used to constrain the chemistry transport model scheme in the future study. The series of oxidant observations such as $\mathrm{O}_{3}$ (Legrand et al., 2009, 2016a), $\mathrm{HO}_{x}$ (Kukui et al., 2012, 2014) and $\mathrm{NO}_{x}$ (Grilli et al., 2013) have demonstrated that due to the katabatic winds, air masses on the East Antarctic plateau enriched in oxidants produced via reactive nitrogen emission from surface snow and subsequent interactive reactions between $\mathrm{HO}_{x}, \mathrm{NO}_{x}$, and $\mathrm{RO}_{2}$, are frequently exported to DDU. Legrand et al. (2009, 2016a) also suggested that the influence of bromine chemistry is much less significant in East Antarctica compared to a western coastal site such as Halley and Neumayer. However, besides the framework of that project, model-aided analyses of $\Delta^{17} \mathrm{O}\left(\mathrm{SO}_{4}^{2-}\right)$ observations by Chen et al. (2016) pointed out the significant contribution (33-50\%) of $\mathrm{SO}_{2}$ oxidation by hypohalous acids ( $\mathrm{HOX}=\mathrm{HOCl}$ and $\mathrm{HOBr}$ ) on total sulfate production in the remote marine boundary layer including the Southern Ocean, indicating the possibility of its influence in the coastal Antarctic site. Hence, we then aimed to reveal any features of the oxidation mechanisms of their precursors based on the seasonality of $\Delta^{17} \mathrm{O}\left(\mathrm{SO}_{4}^{2-}\right)$ and $\Delta^{17} \mathrm{O}\left(\mathrm{NO}_{3}^{-}\right)$ values at this specific site.

\section{Samples and analytical methods}

\subsection{Sampling site and aerosol sample collection}

\subsubsection{Sampling site}

Samples were collected at DDU $\left(66^{\circ} 40^{\prime} \mathrm{S}, 140^{\circ} 01^{\prime} \mathrm{E}\right.$; $40 \mathrm{~m}$ a.s.1.), located on a small island $1 \mathrm{~km}$ off the coast of Antarctica. The climate of DDU is described in KonigLanglo et al. (1998). Compared with other parts of Antarctica, DDU is temperate, with temperatures ranging from -30 to $5^{\circ} \mathrm{C}$ throughout the year. Most parts of the island are free of snow, and the sea ice disappears completely during most of the summers. Recent observations of surface ozone and the $\mathrm{OH}$ radical (Legrand et al., 2016a; Kukui et al., 2012) revealed that at $\mathrm{DDU}, \mathrm{O}_{3}$ and $\mathrm{OH}$ levels are approximately 2 and 10 times higher, respectively, compared to the Palmer Station (Jefferson et al., 1998), due to the transportation of air masses influenced by the snowpack emission of reactive nitrogen species on the East Antarctic plateau and the subsequent oxidant productions.

\subsubsection{Aerosol sample collection}

Aerosol samples were collected using a high-volume air sampler (HVAS; General Metal Works GL 2000H Hi Vol TSP; Tisch Environmental, Cleves, OH, USA). Coarse $(>1 \mu \mathrm{m})$ and fine $(<1 \mu \mathrm{m})$ particles were collected separately using a four-stage cascade impactor and a backup glass fiber filter, respectively. The slotted $12.7 \mathrm{~cm} \times 17.8 \mathrm{~cm}$ glass fiber filters were mounted on the cascade impactor, while the
$20.3 \mathrm{~cm} \times 25.4 \mathrm{~cm}$ glass fiber filters were used for backup. The HVAS was placed on a platform $1 \mathrm{~m}$ above ground, $50 \mathrm{~m}$ from the coast, and $20 \mathrm{~m}$ away from the closest building. Aerosol collection was carried out at weekly intervals, with flow rates of $\sim 1.5 \mathrm{~m}^{3} \mathrm{~min}^{-1}$, yielding an average pumped air volume of $15000 \mathrm{~m}^{3}$ per sample. Samples collected between January 2011 and January 2012 were used for this study. Once per month, a field blank was checked by mounting filters onto the filter holder and running the cascade impactor for $1 \mathrm{~min}$.

After each collection period, the filters were removed from the cascade impactor inside a clean chemical hood; they were wrapped in aluminum foil and stored in plastic bags at $-20^{\circ} \mathrm{C}$. The four filters on the impactor stage were grouped together as coarse particle samples, while the backup filters were kept as fine particle samples. Samples were transported back to the Université Grenoble Alpes (France) for chemical and isotopic analyses, while frozen.

\subsubsection{Quantification of ionic species}

The soluble compounds in the aerosols were extracted with ultrapure water (Millipore filter, $18 \mathrm{M} \Omega \mathrm{cm}$; EMD Millipore, MA, USA) according to the process described in Savarino et al. (2007); more than $98 \%$ of the initial water volume was recovered. Field blank filters were processed in the same way.

Small aliquots of these sample solutions were taken for quantification of ionic species. Anion $\left(\mathrm{Cl}^{-}, \mathrm{NO}_{3}^{-}, \mathrm{SO}_{4}^{2-}\right)$ and sodium $\left(\mathrm{Na}^{+}\right)$concentrations were analyzed using the ion chromatography systems described in Savarino et al. (2007) and Jourdain and Legrand (2002), respectively.

Atmospheric concentrations of these ionic species were calculated using the aerosol loading for each filter, the mean filter blank values, and the air volume pumped through the filter. The air volume was corrected to standard temperature and pressure $(T=273.15 \mathrm{~K}, p=101325 \mathrm{~Pa})$ based on the meteorological data from DDU provided by Meteo France. The uncertainties for atmospheric concentrations were calculated by propagating the typical uncertainty of the ion chromatography analysis $(5 \%)$ and the standard deviation $(1 \sigma)$ of filter blank values.

\subsection{Oxygen isotopic analyses of sulfate and nitrate in aerosols}

\subsubsection{Definition of triple oxygen isotopic compositions}

Given the two isotope ratios, notated as ${ }^{17} R\left(={ }^{17} \mathrm{O} /{ }^{16} \mathrm{O}\right)$ and ${ }^{18} R\left(={ }^{18} \mathrm{O} /{ }^{16} \mathrm{O}\right)$, stable oxygen isotope ratios are conventionally scaled using a delta $(\delta)$ notation as follows.

$\delta^{x} \mathrm{O}=\frac{{ }^{x} R_{\text {sample }}}{{ }^{x} R_{\text {VSMOW }}}-1$,

where $R_{\text {VSMOW }}$ denotes the isotope ratio of the standard material, Vienna Standard Mean Ocean Water (VSMOW), and 
$x$ is 17 or 18 . Despite the robust relationship of the massdependent law $\left(\delta^{17} \mathrm{O}=0.52 \times \delta^{18} \mathrm{O}\right)$ in most of the oxygencontaining species (e.g., $\mathrm{O}_{2}$ and $\mathrm{H}_{2} \mathrm{O}$ ), atmospheric ozone does not follow mass-dependent fractionation and possesses a significant positive $\Delta^{17} \mathrm{O}\left(=\delta^{17} \mathrm{O}-0.52 \times \delta^{18} \mathrm{O}\right)$ inherited from mass-independent fractionation associated with its formation process (Gao and Marcus, 2001). Since non-zero $\Delta^{17} \mathrm{O}$ values can be observed in various atmospheric species bearing oxygen atoms inherited from $\mathrm{O}_{3}$ (e.g., sulfate and nitrate), the $\Delta^{17} \mathrm{O}$ signature is a powerful tracer used to investigate the relative contribution of $\mathrm{O}_{3}$ to oxidation processes.

\subsubsection{Oxygen isotopic analysis of sulfate and data correction}

All $\Delta^{17} \mathrm{O}$ values of sulfate were measured with an isotope ratio mass spectrometer (IRMS) (MAT253; Thermo Fisher Scientific, Bremen, Germany), coupled with an inhouse measurement system at the Tokyo Institute of Technology. The measurement system for $\Delta^{17} \mathrm{O}\left(\mathrm{SO}_{4}^{2-}\right)$ follows Savarino et al. (2001) with modifications described in several studies (Schauer et al., 2012; Geng et al., 2013). Briefly, $1 \mu \mathrm{mol}$ of sulfate was separated from other ions using an ion chromatography system (Dionex ICS-2100, Thermo Fisher Scientific). The sample was pumped at a flow rate of $1 \mathrm{~mL} \mathrm{~min}^{-1}$ to the pre-concentration column (Dionex IonPac AG15, $4 \mathrm{~mm} \times 50 \mathrm{~mm}$, Thermo Fisher Scientific) to collect all anions contained in the sample. After the sample was loaded on the pre-concentration column, the anions were eluted by $\mathrm{KOH}$ eluent to the guard column (Dionex IonPac AG19, $4 \mathrm{~mm} \times 50 \mathrm{~mm}$, Thermo Fisher Scientific) and the separation column (Dionex IonPac AS19, $4 \mathrm{~mm} \times 250 \mathrm{~mm}$, Thermo Fishier Scientific). The separated sulfate was collected in a vial using a fraction collector (CHF122SC, ADVANTEC). The sulfate was chemically converted to silver sulfate $\left(\mathrm{Ag}_{2} \mathrm{SO}_{4}\right)$. This $\mathrm{Ag}_{2} \mathrm{SO}_{4}$ powder is transported in a custom-made quartz cup, which is dropped into a furnace at $1000^{\circ} \mathrm{C}$ within a high temperature conversion elemental analyzer (TC/EA; Thermo Fisher Scientific, Bremen, Germany) and thermally decomposed into $\mathrm{O}_{2}$ and $\mathrm{SO}_{2}$. Gas products from this sample pyrolysis are carried by ultrahighpurity $\mathrm{He}$ (>99.99995 \% purity; Japan Air Gases Co., Tokyo, Japan), which is first purified using a molecular sieve $(5 \AA)$ held at $-196^{\circ} \mathrm{C}$ (Hattori et al., 2015). The gas products $\mathrm{O}_{2}$ and $\mathrm{SO}_{2}$ are carried through a cleanup trap (trap 1) held at $-196^{\circ} \mathrm{C}$ to trap $\mathrm{SO}_{2}$ and trace $\mathrm{SO}_{3}$, while $\mathrm{O}_{2}$ continues to another molecular sieve ( $5 \AA$ ) in a $1.59 \mathrm{~mm}$ o. d. tubing trap (trap 2) held at $-196^{\circ} \mathrm{C}$ to trap $\mathrm{O}_{2}$ separately from the other gas products. The $\mathrm{O}_{2}$ is purified using a gas chromatograph with a CP-Molsieve $(5 \AA)$ column $(0.32 \mathrm{~mm}$ i. d., $30 \mathrm{~m}$ length, $10 \mu \mathrm{m}$ film; Agilent Technologies Inc., Santa Clara, CA, USA) held at $40^{\circ} \mathrm{C}$ before being introduced to the IRMS system to measure $m / z=32,33$, and 34. The interlaboratory calibrated standards (Sulf- $\alpha, \beta$, and $\varepsilon$; Schauer et al., 2012) were used to assess the accuracy of our measure-

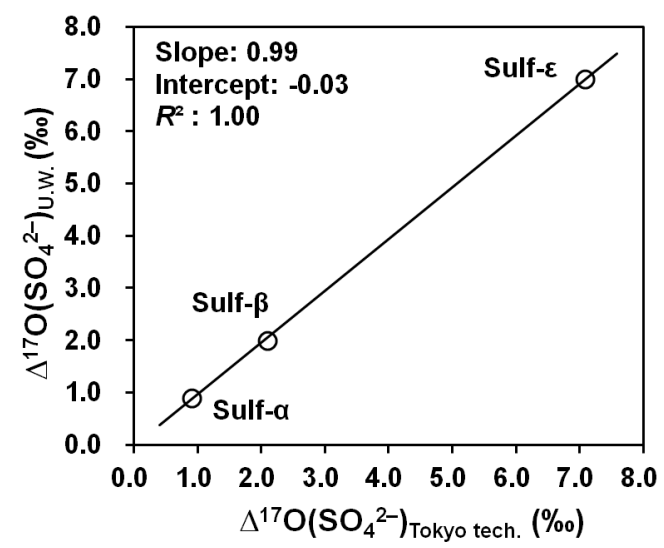

Figure 1. Comparison of $\Delta^{17} \mathrm{O}$ values of sulfate for standard materials measured at the University of Washington (U.W.) and the Tokyo Institute of Technology (Tokyo tech.).

ments; our values were in good agreement with published ones (Fig. 1). As discussed by Schauer et al. (2012), this method results in the oxygen isotope exchange between the $\mathrm{O}_{2}$ products and the quartz cups as well as the quartz reactor, which shifts $\delta^{17} \mathrm{O}, \delta^{18} \mathrm{O}$, and thus $\Delta^{17} \mathrm{O}$ measurements. The shift in the $\Delta^{17} \mathrm{O}\left(\mathrm{SO}_{4}^{2-}\right)$ value is corrected by estimating the magnitude of the oxygen isotope exchange with quartz materials, whose $\Delta^{17} \mathrm{O}$ value is assumed to be approximately $0 \%$ 。 (Matsuhisa et al., 1978). The intercept of -0.03 in Fig. 1 also supports this assumption. Since the $\delta^{17} \mathrm{O}$ and $\delta^{18} \mathrm{O}$ values of each quartz material used in this study are not known, the corrected $\delta^{17} \mathrm{O}$ and $\delta^{18} \mathrm{O}$ values of $\mathrm{SO}_{4}^{2-}$ shown in the Supplement are unreliable and, therefore, we don't discuss these values. Note that those $\delta^{17} \mathrm{O}$ and $\delta^{18} \mathrm{O}$ values of $\mathrm{SO}_{4}^{2-}$ are relative values to our $\mathrm{O}_{2}$ reference gas. The precision of $\Delta^{17} \mathrm{O}$ is typically better than $\pm 0.2 \%$ based on replicate analyses of the standards.

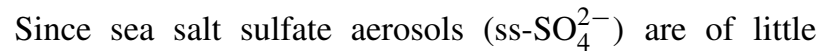
importance to the atmospheric sulfur oxidation processes

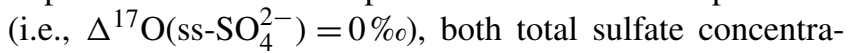
tions and $\Delta^{17} \mathrm{O}$ values were corrected for their ss-SO $\mathrm{SO}_{4}^{2-}$ component to obtain their non-sea salt sulfate (nss- $\mathrm{SO}_{4}^{2-}$ ) content using Eqs. (2) and (3) below.

$$
\begin{aligned}
& {\left[\mathrm{nss}-\mathrm{SO}_{4}^{2-}\right]=\left[\text { total }-\mathrm{SO}_{4}^{2-}\right]-k \times\left[\mathrm{Na}^{+}\right],} \\
& \begin{aligned}
\Delta^{17} \mathrm{O}\left(\mathrm{nss}-\mathrm{SO}_{4}^{2-}\right) & =\frac{\left[\text { total }-\mathrm{SO}_{4}^{2-}\right]}{\left[\mathrm{nss}-\mathrm{SO}_{4}^{2-}\right]} \\
& \times \Delta^{17} \mathrm{O}\left(\text { total }-\mathrm{SO}_{4}^{2-}\right),
\end{aligned}
\end{aligned}
$$

where "total" is the quantity measured by ion chromatography, corresponding to the sum of ss- and nss- $\mathrm{SO}_{4}^{2-}$ components, and $k$ is the mass ratio of $\left[\mathrm{SO}_{4}^{2-}\right] /\left[\mathrm{Na}^{+}\right]$in sea water $(0.25$; Holland et al., 1986). To take into account the sea 
salt chemical fractionation processes that affect the Antarctic region in winter, when temperatures drop below $-8^{\circ} \mathrm{C}$ in the presence of sea ice (Wagenbach et al., 1998), we used a $k$ value of $0.13 \pm 0.04$, estimated previously by Jourdain and Legrand (2002) from the winter average at DDU and confirmed by our own dataset; this was applied to samples collected from May to October. Note that the sea salt fractionation is a chemical fractionation and is different from an isotopic fractionation. Equation (3) is the isotope mass balance equation between ss- and nss- $\mathrm{SO}_{4}^{2-}$, with $\Delta^{17} \mathrm{O}$ (ss$\left.\mathrm{SO}_{4}^{2-}\right)=0 \%$. The total uncertainties for $\Delta^{17} \mathrm{O}\left(\mathrm{nss}-\mathrm{SO}_{4}^{2-}\right)$ values were calculated using the precision of $\Delta^{17} \mathrm{O}$ measurement and the uncertainty of $k$ value, resulting in the uncertainty of $\pm 1.9 \%$ at maximum. The propagated error for both [nss- $\mathrm{SO}_{4}^{2-}$ ] and $\Delta^{17} \mathrm{O}\left(\mathrm{nss}-\mathrm{SO}_{4}^{2-}\right)$ values are shown in the Supplement.

The measurement of $\Delta^{17} \mathrm{O}\left(\mathrm{SO}_{4}^{2-}\right)$ values were only performed for the fine mode samples because the sulfate in the coarse mode samples consists of more than $80 \%$ ss- $\mathrm{SO}_{4}^{2-}$. The influence of ornithogenic soil emissions on $\mathrm{Na}^{+}$and $\mathrm{SO}_{4}^{2-}$ concentrations was not taken into account since it mainly affects supermicron (coarse) aerosols (Jourdain and Legrand, 2002).

\subsubsection{Oxygen isotopic analysis of nitrate}

The $\Delta^{17} \mathrm{O}$ value of nitrate was measured simultaneously with $\delta^{18} \mathrm{O}$ and $\delta^{15} \mathrm{~N}$ values using a bacterial denitrifier method (Casciotti et al., 2002) coupled with an IRMS measurement using our in-house peripheral system at the Université Grenoble Alpes (Morin et al., 2009). All nitrates in our samples were converted to $\mathrm{N}_{2} \mathrm{O}$ via bacterial denitrification. This $\mathrm{N}_{2} \mathrm{O}$ was introduced to the measurement system, separated from $\mathrm{CO}_{2}, \mathrm{H}_{2} \mathrm{O}$, and other volatile organic compounds, and pre-concentrated in a cold trap. The trapped $\mathrm{N}_{2} \mathrm{O}$ was converted into $\mathrm{O}_{2}$ and $\mathrm{N}_{2}$ by pyrolysis at $900^{\circ} \mathrm{C}$, using a gold tube furnace, followed by separation of $\mathrm{O}_{2}$ and $\mathrm{N}_{2}$ via a $10 \mathrm{~m}$ Molsieve ( $5 \AA$ ) gas chromatography column before being introduced to the IRMS system. Measurements were performed simultaneously for samples equivalent to $100 \mathrm{nmol}$ nitrate as well as a subset of international nitrate reference materials (US Geological Survey 32, 34, and 35, as well as their mixtures) for correction and calibration of $\Delta^{17} \mathrm{O}$ and $\delta^{18} \mathrm{O}$ values relative to VSMOW and $\delta^{15} \mathrm{~N}$ values relative to air $\mathrm{N}_{2}$. Analytical uncertainty was estimated based on the standard deviation of the residuals from a linear regression between the measured reference materials and their expected values. The uncertainties $(1 \sigma)$ for $\Delta^{17} \mathrm{O}\left(\mathrm{NO}_{3}^{-}\right)$and $\delta^{15} \mathrm{~N}\left(\mathrm{NO}_{3}^{-}\right)$were 0.4 and $0.3 \%$, respectively.

\subsection{Sampling and analytical methods of the oxygen isotopic composition of ozone}

The sampling and isotopic analysis of surface ozone were performed by coupling the nitrite-coated filter method with the nitrate isotopic measurements described in Vicars et al. $(2012,2014)$. The principle of ozone collection underlying this technique is the filter-based chemical trapping of ozone via its reaction with nitrite:

$\mathrm{NO}_{2}^{-}+\mathrm{O}_{3} \rightarrow \mathrm{NO}_{3}^{-}+\mathrm{O}_{2}$

During Reaction (R1), one of the three oxygen atoms of nitrate is transferred from one of the two terminal oxygen atoms of ozone, while the other two oxygen atoms are derived from the reagent nitrite. Since the $\Delta^{17} \mathrm{O}$ signature of ozone is only located on the terminal atoms of ozone (Bhattacharya et al., 2008; Janssen and Tuzson, 2006), simple mass balance implies that $\Delta^{17} \mathrm{O}\left(\mathrm{O}_{3}\right)_{\text {term }}$ is $2 / 3$ of $\Delta^{17} \mathrm{O}\left(\mathrm{O}_{3}\right)_{\text {bulk. Thus, }}{ }^{17} \mathrm{O}\left(\mathrm{O}_{3}\right)_{\text {term }}$ values can be inferred using the simple mass balance of Eq. (4):

$\Delta^{17} \mathrm{O}\left(\mathrm{O}_{3}\right)_{\text {term. }}=3 \times \Delta^{17} \mathrm{O}\left(\mathrm{NO}_{3}^{-}\right)-2 \times \Delta^{17} \mathrm{O}\left(\mathrm{NaNO}_{2}\right)$,

where $\Delta^{17} \mathrm{O}\left(\mathrm{NaNO}_{2}\right)$ of the reagent is confirmed to be zero (Vicars et al., 2012). Therefore, the $\Delta^{17} \mathrm{O}$ value of ozone can be determined from the oxygen isotopic composition of nitrate produced on the coated filter via Reaction (R1), determined by the same measurement system described above.

Ozone sampling was carried out by pumping ambient air, using a low-volume vacuum pump (Model 2522C-02; Welch, IL, USA), through a glass fiber filter $(\varnothing 47 \mathrm{~mm}, \mathrm{GF} / \mathrm{A}$ type; Whatman, UK) pre-coated with a mixture of $\mathrm{NaNO}_{2}$, $\mathrm{K}_{2} \mathrm{CO}_{3}$, and glycerol. Sampling was conducted once per week from May 2011 to April 2012, with 24-48 h sampling intervals. After sampling, filter samples and procedural blanks were extracted in $18 \mathrm{M} \Omega$ water. Any unreacted nitrite reagent was removed using the reaction with sulfamic acid and neutralized later with $\mathrm{NaOH}$ solutions (Granger and Sigman, 2009; Vicars et al., 2012). The sample solutions were stored in the dark at $-20^{\circ} \mathrm{C}$ and transported back to Grenoble. After the nitrate concentration analysis using a colorimetric technique (Frey et al., 2009), the isotopic analysis of nitrate (i.e., ozone) was performed using the same protocol as the nitrate isotope analysis. In addition to the isotope measurements of ozone, we aligned the mixing ratio of surface ozone to the weekly average using data reported in Legrand et al. (2016a) to fit the time resolution of our aerosol sampling.

\subsection{Complementary analyses}

To investigate relationships between the origins of the air masses and the $\Delta^{17} \mathrm{O}$ signatures of sulfate and nitrate, transport pathways of sampled air masses were analyzed using the NOAA's HYSPLIT (Hybrid Single-Particle Lagrangian Integrated Trajectory) model (Stein et al., 2015). The model was used with NCEP-NCAR reanalysis data fields using a regular $2.5^{\circ} \times 2.5^{\circ}$ longitude-latitude grid. Five-day backward trajectories for air masses arriving at the DDU at an altitude 
of $40 \mathrm{~m}$ a.s.l. were computed twice per day for each day during sampling periods.

The sea ice area fraction around the Antarctic continent was derived from the Advanced Microwave Scanning Radiometer on-board NASA's Earth Observing System Aqua satellite using the ARTIST sea ice algorithm (Kaleschke et al., 2001). The contact times of these air masses with the Antarctic continent and sea ice were calculated using fiveday backward trajectories and sea ice area fractions.

\section{Results}

\subsection{Sulfate}

Seasonal variations in atmospheric concentrations and $\Delta^{17} \mathrm{O}$ values of $\mathrm{SO}_{4}^{2-}$ are shown in Fig. 2a. Atmospheric concentrations of nss- $\mathrm{SO}_{4}^{2-}$ showed a clear seasonal trend. The [nss$\mathrm{SO}_{4}^{2-}$ ] had a maximum of up to $\sim 280 \mathrm{ng} \mathrm{m}^{-3}$ from January to February, corresponding to the austral summer period, but decreased to a background level $\left(\sim 10 \mathrm{ng} \mathrm{m}^{-3}\right)$ during the May to August winter period before increasing as summer returned. This trend in [nss- $\mathrm{SO}_{4}^{2-}$ ] at coastal Antarctic sites results from enhanced marine biogenic activity emitting dimethyl sulfide (DMS) in circum-Antarctic regions in summer, as has often been reported previously (e.g., Wagenbach et al., 1998; Minikin et al., 1998; Jourdain and Legrand, 2002; Preunkert et al., 2008). As Antarctica is surrounded by ocean, DMS is the major source of atmospheric non-sea salt sulfur (Minikin et al., 1998; Jourdain and Legrand, 2002). Interestingly, a sample from 18-25 July had an anomalously high value of $46 \mathrm{ng} \mathrm{m}^{-3}$, four times the monthly mean level for July $\left(\sim 12 \mathrm{ng} \mathrm{m}^{-3}\right)$.

The $\Delta^{17} \mathrm{O}\left(\mathrm{nss}-\mathrm{SO}_{4}^{2-}\right)$ values showed the reverse trend, with a summer minimum and a winter maximum. The $\Delta^{17} \mathrm{O}\left(\mathrm{nss}-\mathrm{SO}_{4}^{2-}\right)$ value increased from $1.0 \%$ observed in January to a maximum of $3.4 \%$ at the end of June, decreasing to $0.9 \%$ in December. The annual weighted mean value of $\Delta^{17} \mathrm{O}\left(\mathrm{nss}-\mathrm{SO}_{4}^{2-}\right.$ ) was $1.4 \pm 0.1 \%$. Higher values (greater than $2 \%$ o) were generally observed during April to July, but the anomalous peak from 18-25 July was characterized by a low $\Delta^{17} \mathrm{O}\left(\right.$ nss- $\left.\mathrm{SO}_{4}^{2-}\right)$ value of $0.9 \%$. Consequently, the monthly mean value had a maximum in July $(2.6 \pm 0.6 \%$ ) when the 18-25 July data were excluded.

\subsection{Nitrate}

Seasonal variations in atmospheric concentrations and $\Delta^{17} \mathrm{O}$ values for nitrate are shown in Fig. 2b. Nitrate concentrations increased to $55 \mathrm{ng} \mathrm{m}^{-3}$ in January but gradually decreased to less than $10 \mathrm{ng} \mathrm{m}^{-3}$ in March to May. In July, a significant peak of $28 \mathrm{ng} \mathrm{m}^{-3}$ was observed, followed by a seasonal increase as summer returned. The $\Delta^{17} \mathrm{O}\left(\mathrm{NO}_{3}^{-}\right)$values showed a simple seasonal variation with a summer minimum and a winter maximum. $\Delta^{17} \mathrm{O}\left(\mathrm{NO}_{3}^{-}\right)$increased from $27 \%$ in Jan-

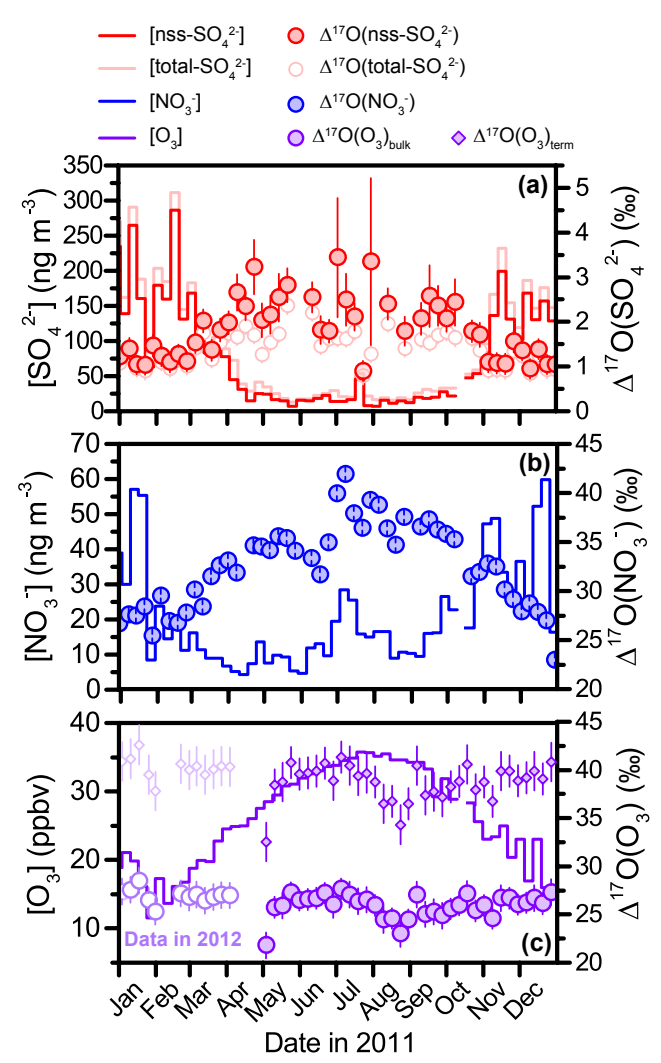

Figure 2. Seasonal variations of concentrations (solid line) and $\Delta{ }^{17} \mathrm{O}$ values (circles) of sulfate (red), nitrate (blue), and ozone (purple) at the Dumont d'Urville Station during 2011. $\Delta^{17} \mathrm{O}$ values of ozone are shown as bulk (circle) and terminal (square) values. $\Delta^{17} \mathrm{O}$ values of ozone include samples collected from January to April 2012.

uary to over $40 \%$ in July, decreasing moderately to a minimum value of $23 \%$ in December. These trends in nitrate concentrations and $\Delta^{17} \mathrm{O}\left(\mathrm{NO}_{3}^{-}\right)$values are consistent with those observed at this site 10 years ago (Savarino et al., 2007).

\subsection{Ozone}

Daily averaged ozone mixing ratios are presented in Fig. 2c; these exhibit a distinct seasonal variation with a summer minimum and a winter maximum. The minimum ozone mixing ratio was observed in January, having a value lower than $10 \mathrm{ppbv}$, while the maximum was observed during July to August, having a value higher than 35 ppbv. From November to December, sudden increases in ozone levels to values over 30 ppbv were observed a few times, consistent with seasonal trends for ozone at DDU (Legrand et al., 2009). The $\Delta{ }^{17} \mathrm{O}\left(\mathrm{O}_{3}\right)_{\text {bulk }}$ values showed an insignificant variation, with a summer maximum of $28 \%$, a winter minimum of $23 \%$, and an annual mean $\Delta{ }^{17} \mathrm{O}\left(\mathrm{O}_{3}\right)_{\text {bulk value of } 26 \pm 1 \% \text {. }}$ 


\section{Discussion}

\section{1 $\quad \Delta^{17} \mathrm{O}$ values and atmospheric formation pathways of sulfate and nitrate}

Atmospheric sulfate and nitrate are produced from the oxidation of their precursor, $\mathrm{SO}_{2}$ and $\mathrm{NO}_{x}$, by various oxidants. Therefore, the $\Delta^{17} \mathrm{O}\left(\mathrm{SO}_{4}^{2-}\right)$ and $\Delta^{17} \mathrm{O}\left(\mathrm{NO}_{3}^{-}\right)$values for sulfate and nitrate produced via each oxidation pathways are determined by the $\Delta^{17} \mathrm{O}$ values of their precursors and the $\Delta^{17} \mathrm{O}$ values of oxidants, which provides oxygen atoms to the products in different transferring factors. To interpret our data, we estimated the $\Delta^{17} \mathrm{O}\left(\mathrm{SO}_{4}^{2-}\right)$ and $\Delta^{17} \mathrm{O}\left(\mathrm{NO}_{3}^{-}\right)$values produced via each oxidation pathway. The $\Delta^{17} \mathrm{O}\left(\mathrm{SO}_{4}^{2-}\right)$ and $\Delta^{17} \mathrm{O}\left(\mathrm{NO}_{3}^{-}\right)$values for the oxidation by $\mathrm{O}_{3}$ were estimated using the mean $\Delta^{17} \mathrm{O}\left(\mathrm{O}_{3}\right)$ value (i.e., $26 \%$ ) observed in this study. Each oxidation pathway and corresponding $\Delta^{17} \mathrm{O}$ value of the products sulfate and nitrate are summarized in Table 1.

\subsection{1 $\quad \Delta^{17} \mathrm{O}$ values of sulfate}

Since $\mathrm{SO}_{2}$ quickly exchanges its oxygen atoms with abundant water vapor in the atmosphere, the $\Delta^{17} \mathrm{O}\left(\mathrm{SO}_{2}\right)$ value is assumed to be $0 \%$ (Holt et al., 1983). Thus, the $\Delta^{17} \mathrm{O}\left(\mathrm{SO}_{4}^{2-}\right)$ value is only dependent on the oxidation pathway of $\mathrm{SO}_{2}$ to $\mathrm{SO}_{4}^{2-} \cdot \mathrm{SO}_{2}$ oxidation by $\mathrm{OH}$ $\left(\Delta^{17} \mathrm{O}(\mathrm{OH})=\sim 0 \%\right.$ ) in the gas phase produces sulfuric acid $\left(\mathrm{H}_{2} \mathrm{SO}_{4}\right)$ which possesses the $\Delta^{17} \mathrm{O}\left(\mathrm{SO}_{4}^{2-}\right)$ value of approximately $0 \%$.

$\mathrm{SO}_{2}+\mathrm{OH} \stackrel{\mathrm{O}_{2}, \stackrel{\mathrm{H}_{2} \mathrm{O}}{\longrightarrow}, \mathrm{M}}{\longrightarrow} \mathrm{H}_{2} \mathrm{SO}_{4}$.

$\mathrm{SO}_{2}$ can also dissolve into the aqueous phase on aerosol surfaces, where it can be oxidized by $\mathrm{O}_{3}, \mathrm{H}_{2} \mathrm{O}_{2}$, or metalcatalyzed oxidation by $\mathrm{O}_{2}$ to form sulfate (Seinfeld and Pandis, 2006). Given that $\Delta^{17} \mathrm{O}\left(\mathrm{O}_{3}\right)_{\text {bulk }}$ values of approximately $26 \%$ have been observed, the $\Delta^{17} \mathrm{O}\left(\mathrm{SO}_{4}^{2-}\right)$ value of sulfate produced by ozone should be around $6.5 \%$, based on a $\Delta^{17} \mathrm{O}$ signature transfer factor of 0.25 (Savarino et al., 2000).

$\mathrm{SO}_{3}^{2-}+\mathrm{O}_{3} \longrightarrow \mathrm{SO}_{4}^{2-}+\mathrm{O}_{2}$.

Given the $\Delta^{17} \mathrm{O}\left(\mathrm{H}_{2} \mathrm{O}_{2}\right)$ values of $1.6 \%$ on average (Savarino and Thiemens, 1999), the $\Delta^{17} \mathrm{O}\left(\mathrm{SO}_{4}^{2-}\right)$ of sulfate produced by $\mathrm{H}_{2} \mathrm{O}_{2}$ is estimated to be $0.8 \%$, using a transfer factor of 0.5 (Savarino et al., 2000).

$\mathrm{HSO}_{3}^{2-}+\mathrm{H}_{2} \mathrm{O}_{2} \longrightarrow \mathrm{HSO}_{4}^{-}+\mathrm{H}_{2} \mathrm{O}$.

The $\Delta^{17} \mathrm{O}\left(\mathrm{O}_{2}\right)$ value was measured to be $-0.3 \%$ (Barkan and Luz, 2003), producing sulfate with a $\Delta^{17} \mathrm{O}\left(\mathrm{SO}_{4}^{2-}\right)$ value of almost $0 \%$ (Savarino et al., 2000).

$\mathrm{SO}_{3}^{2-}+\mathrm{O}_{2} \stackrel{\mathrm{Fe}, \mathrm{Mn}}{\longrightarrow} \mathrm{SO}_{4}^{2-}$.
Additionally, aqueous phase $\mathrm{SO}_{2}$ oxidation by hypohalous acids $(\mathrm{HOX}=\mathrm{HOCl}$ and $\mathrm{HOBr}$ ) has been proposed as one of the major reactions in the marine boundary layer (Vogt et al., 1996; von Glasow et al., 2002). Details are discussed in Sect. 4.3. Thus, $\Delta^{17} \mathrm{O}\left(\mathrm{SO}_{4}^{2-}\right)$ of nss- $\mathrm{SO}_{4}^{2-}$ results from a subtle balance between various oxidation reactions, with each one transferring a specific amount of $\Delta{ }^{17} \mathrm{O}$ signature to sulfate.

\subsection{2 $\quad \Delta^{17} \mathrm{O}$ values of nitrate}

The $\Delta^{17} \mathrm{O}\left(\mathrm{NO}_{3}^{-}\right)$value is dependent on both the $\Delta^{17} \mathrm{O}\left(\mathrm{NO}_{2}\right)$ value and the oxidation pathways of $\mathrm{NO}_{2}$ to $\mathrm{NO}_{3}^{-}$. The $\Delta^{17} \mathrm{O}\left(\mathrm{NO}_{2}\right)$ value is determined by the relative contribution of NO oxidation pathways during the following photochemical cycle.

$\mathrm{NO}_{2} \longrightarrow \mathrm{NO}+\mathrm{O}\left({ }^{3} \mathrm{P}\right)$

$\mathrm{NO}+\mathrm{O}_{3} \longrightarrow \mathrm{NO}_{2}+\mathrm{O}_{2}$,

$\mathrm{NO}+\mathrm{RO}_{2} \longrightarrow \mathrm{NO}_{2}+\mathrm{RO}$.

Since all non-zero $\Delta^{17} \mathrm{O}$ of ozone are positioned in the terminal oxygen atoms (Bhattacharya et al., 2008), which preferentially react with $\mathrm{NO}$ (Savarino et al., 2008), the $\mathrm{NO}_{2}$ formed by ozone exhibits a higher isotopic value than the bulk $\Delta^{17} \mathrm{O}\left(\mathrm{O}_{3}\right)$. On the other hand, the $\mathrm{NO}+\mathrm{RO}_{2}$ reaction produces nitrate with a lower $\Delta^{17} \mathrm{O}\left(\mathrm{NO}_{3}^{-}\right)$value because $\Delta^{17} \mathrm{O}\left(\mathrm{RO}_{2}\right)$ is approximately $0 \%$ (Morin et al., 2007). $\mathrm{NO}_{2}$ is then converted into nitrate through one of the following reactions.

$\mathrm{NO}_{2}+\mathrm{OH} \stackrel{\mathrm{M}}{\longrightarrow} \mathrm{HNO}_{3}$,

$\mathrm{NO}_{2}+\mathrm{O}_{3} \longrightarrow \mathrm{NO}_{3}$,

$\mathrm{NO}_{3} \stackrel{h v}{\longrightarrow} \mathrm{NO}_{2}+\mathrm{O}\left({ }^{3} \mathrm{P}\right)$,

$\mathrm{NO}_{3}+\mathrm{RH} \longrightarrow \mathrm{HNO}_{3}+$ products,

$\mathrm{NO}_{3}+\mathrm{NO}_{2} \stackrel{\mathrm{M}}{\Leftrightarrow} \mathrm{N}_{2} \mathrm{O}_{5} \stackrel{\mathrm{H}_{2} \mathrm{O}}{\longrightarrow} 2 \mathrm{HNO}_{3}$.

It has been pointed out that $\mathrm{BrO}$ plays a significant role in both $\mathrm{NO}$ and $\mathrm{NO}_{2}$ oxidation in the marine boundary layer (Savarino et al., 2013) through the following reactions:

$\mathrm{NO}+\mathrm{BrO} \longrightarrow \mathrm{NO}_{2}+\mathrm{Br}$,

$\mathrm{NO}_{2}+\mathrm{BrO} \longrightarrow \mathrm{BrONO}_{2} \stackrel{\mathrm{H}_{2} \mathrm{O}}{\longrightarrow} \mathrm{HNO}_{3}+\mathrm{HOBr}$.

The oxidation by $\mathrm{BrO}$ may also produce $\mathrm{NO}_{2}$ and nitrate with high $\Delta^{17} \mathrm{O}$ values (Morin et al., 2007), because $\mathrm{BrO}$ is thought to possess the terminal oxygen atom of ozone (Bhattacharya et al., 2008). Note that these reactions are thought to have little importance ( $2 \%$ at maximum) on the Antarctic plateau during the austral summer due to low $\mathrm{BrO}$ levels of up to 2-3 $\mathrm{pmol} \mathrm{mol}^{-1}$ (Frey et al., 2015; Savarino et al., 2016).

Following the principle that two of the three oxygen atoms in $\mathrm{NO}_{3}^{-}$come from $\mathrm{NO}_{2}$ and one arises through conversion 
Table 1. Summary of $\Delta^{17} \mathrm{O}$ values of sulfate and nitrate produced via each reaction pathway with oxidants. $\Delta^{17} \mathrm{O}$ values of sulfate are calculated based on Savarino et al. (2000). $\Delta^{17} \mathrm{O}$ values of nitrate refer to the estimate of the box model by Morin et al. (2011). $\Delta^{17} \mathrm{O}$ values of nitrate produced by $\mathrm{BrONO}_{2}$ hydrolysis is assumed to be equal to the value for the $\mathrm{NO}_{3}+\mathrm{RH}_{\text {pathway. }}$.

\begin{tabular}{llllr}
\hline & Oxidation pathway & $\Delta^{17} \mathrm{O}$ (oxidant) (\%o) & Transferring factor & $\Delta^{17} \mathrm{O}$ (product) (\%o) \\
\hline $\mathrm{SO}_{4}^{2-}$ & $\mathrm{SO}_{2}+\mathrm{OH}$ & $0^{\mathrm{a}}$ & - & 0 \\
& $\mathrm{SO}_{3}^{2-}+\mathrm{O}_{3}$ (aq.) & $26^{\mathrm{b}}$ & $0.25 \times \Delta^{17} \mathrm{O}\left(\mathrm{O}_{3}\right)_{\text {bulk }}$ & 6.5 \\
& $\mathrm{HSO}_{3}^{-}+\mathrm{H}_{2} \mathrm{O}_{2}$ (aq.) & $1.6^{\mathrm{c}}$ & $0.50 \times \Delta^{17} \mathrm{O}\left(\mathrm{H}_{2} \mathrm{O}_{2}\right)$ & 0.8 \\
& $\mathrm{SO}_{3}^{2-}+\mathrm{O}_{2}$ (cat. Fe, Mn) & $-0.3^{\mathrm{d}}$ & $0.25 \times \Delta^{17} \mathrm{O}\left(\mathrm{O}_{2}\right)$ & -0.1 \\
& $\mathrm{SO}_{3}^{2-}+\mathrm{HOX}+\mathrm{H}_{2} \mathrm{O}$ & $39(\mathrm{HOX})^{\mathrm{e}}, 0\left(\mathrm{H}_{2} \mathrm{O}\right)^{\mathrm{f}}$ & - & 0 \\
\hline $\mathrm{NO}_{3}^{-}$ & $\mathrm{NO}_{2}+\mathrm{OH}$ & 0 & $2 / 3 \times \Delta^{17} \mathrm{O}\left(\mathrm{NO}_{2}\right)$ & $17.3-25.1$ \\
& $\mathrm{~N}_{2} \mathrm{O}_{5}$ hydrolysis & $26\left(\mathrm{O}_{3}\right), 0\left(\mathrm{H}_{2} \mathrm{O}\right)$ & $\left.2 / 3 \times \Delta^{17} \mathrm{O}\left(\mathrm{NO}_{2}\right)+1 / 6 \times \Delta^{17} \mathrm{O}_{3} \mathrm{O}_{3}\right)_{\text {term }}$ & $31.0-35.2$ \\
& $\mathrm{NO}_{3}+\mathrm{RH}$ & $26\left(\mathrm{O}_{3}\right)$ & $2 / 3 \times \Delta^{17} \mathrm{O}\left(\mathrm{NO}_{2}\right)+1 / 3 \times \Delta^{17} \mathrm{O}\left(\mathrm{O}_{3}\right)$ term & $38.0-42.7$ \\
& $\mathrm{BrNO}_{2}$ hydrolysis & $39(\mathrm{BrO})^{\mathrm{e}}$ & $2 / 3 \times \Delta^{17} \mathrm{O}\left(\mathrm{NO}_{2}\right)+1 / 3 \times \Delta^{17} \mathrm{O}\left(\mathrm{O}_{3}\right)$ term & $38.0-42.7$ \\
\hline
\end{tabular}

${ }^{\text {a }}$ Holt et al. (1983); ${ }^{\mathrm{b}}$ Vicars and Savarino (2014); ${ }^{\mathrm{c}}$ Savarino and Thiemens (1999); ${ }^{\mathrm{d}}$ Barkan and Luz (2003); ${ }^{\mathrm{e}}$ assumed based on Bhattacharya et al. (2008); ${ }^{\mathrm{f}}$ Barkan and Luz (2005).

of $\mathrm{NO}_{2}$ to $\mathrm{NO}_{3}^{-}$, the $\Delta^{17} \mathrm{O}\left(\mathrm{NO}_{3}^{-}\right)$value of nitrate produced by each pathway can be expressed as Eq. (5).

$\Delta^{17} \mathrm{O}\left(\mathrm{NO}_{3}^{-}\right)=\frac{2}{3} \times \Delta^{17} \mathrm{O}\left(\mathrm{NO}_{2}\right)+\frac{1}{3} \times \Delta^{17} \mathrm{O}($ Oxidant $)$.

For a given value of $\Delta^{17} \mathrm{O}\left(\mathrm{NO}_{2}\right)$, the $\mathrm{NO}_{2}+\mathrm{OH}$ pathway produces the lowest $\Delta^{17} \mathrm{O}\left(\mathrm{NO}_{3}^{-}\right)$value, while the $\mathrm{NO}_{3}+\mathrm{RH}$ pathway or $\mathrm{BrONO}_{2}$ hydrolysis produce the highest $\Delta^{17} \mathrm{O}\left(\mathrm{NO}_{3}^{-}\right)$values.

\subsection{General trend of seasonal variations in $\Delta^{17} \mathrm{O}$ values of sulfate and nitrate}

The $\Delta^{17} \mathrm{O}$ signatures of atmospheric sulfate and nitrate originate from the oxygen transfers from ozone via oxidation of their precursors. Thus, changes in $\Delta^{17} \mathrm{O}\left(\mathrm{O}_{3}\right)$ values likely affect both $\Delta^{17} \mathrm{O}\left(\mathrm{nss}-\mathrm{SO}_{4}^{2-}\right)$ and $\Delta^{17} \mathrm{O}\left(\mathrm{NO}_{3}^{-}\right)$values. However, given the small seasonal variability of the $\Delta^{17} \mathrm{O}\left(\mathrm{O}_{3}\right)_{\text {bulk }}$ (ca. 5\%o) and assuming that all oxygen atoms transferred to $\mathrm{NO}_{x}$ are from the terminal oxygen of ozone, the expected variability of $\Delta^{17} \mathrm{O}\left(\mathrm{nss}-\mathrm{SO}_{4}^{2-}\right)$ and $\Delta^{17} \mathrm{O}\left(\mathrm{NO}_{3}^{-}\right)$should not exceed 1.3 and $7.5 \%$, respectively. Clearly, these upper limits do not explain the 2.5 and $19 \%$ seasonal variability observed in $\Delta^{17} \mathrm{O}\left(\mathrm{nss}-\mathrm{SO}_{4}^{2-}\right)$ and $\Delta^{17} \mathrm{O}\left(\mathrm{NO}_{3}^{-}\right)$at DDU, respectively. Furthermore, the seasonal variation in $\Delta^{17} \mathrm{O}\left(\mathrm{O}_{3}\right)$ values, with a summer maximum and a winter minimum, is the reverse pattern compared to $\Delta^{17} \mathrm{O}\left(\mathrm{nss}-\mathrm{SO}_{4}^{2-}\right)$ and $\Delta^{17} \mathrm{O}\left(\mathrm{NO}_{3}^{-}\right)$values, with a summer minima and a winter maxima. These inconsistencies suggest that variability in $\Delta^{17} \mathrm{O}\left(\mathrm{O}_{3}\right)$ values is not the major factor influencing the seasonal variations in $\Delta^{17} \mathrm{O}\left(\mathrm{nss}-\mathrm{SO}_{4}^{2-}\right)$ and $\Delta^{17} \mathrm{O}\left(\mathrm{NO}_{3}^{-}\right)$values.

Meanwhile, $\Delta^{17} \mathrm{O}\left(\mathrm{nss}-\mathrm{SO}_{4}^{2-}\right)$ and $\Delta^{17} \mathrm{O}\left(\mathrm{NO}_{3}^{-}\right)$values are dependent on the relative importance of various oxidation pathways involved in their formation as described in the pre- vious sections. Since the relative importance of these oxidation pathways is sensitive to the relative concentrations of oxidants in the atmosphere and there is seasonal variation for ozone mixing ratios at a continental scale (Crawford et al., 2001; Legrand et al., 2009), the mixing ratio of ozone is expected to correlate with $\Delta^{17} \mathrm{O}\left(\mathrm{nss}-\mathrm{SO}_{4}^{2-}\right)$ and $\Delta^{17} \mathrm{O}\left(\mathrm{NO}_{3}^{-}\right)$ values. Indeed, $\Delta^{17} \mathrm{O}\left(\mathrm{nss}-\mathrm{SO}_{4}^{2-}\right)$ and $\Delta^{17} \mathrm{O}\left(\mathrm{NO}_{3}^{-}\right)$values, as well as ozone mixing ratios, all display similar seasonal variations, as shown in Fig. 2. The seasonal variation in the ozone mixing ratios at DDU is generally explained by the accumulation of ozone in winter and its photochemical destruction in summer (Legrand et al., 2009, 2016a), which induces the production of $\mathrm{HO}_{x}, \mathrm{RO}_{x}$, and $\mathrm{H}_{2} \mathrm{O}_{2}$ in the summer period. Therefore, we propose that seasonal variations in $\Delta^{17} \mathrm{O}\left(\mathrm{nss}-\mathrm{SO}_{4}^{2-}\right)$ and $\Delta^{17} \mathrm{O}\left(\mathrm{NO}_{3}^{-}\right)$result from a shift in oxidation pathways from $\mathrm{O}_{3}$ to $\mathrm{HO}_{x}, \mathrm{RO}_{x}$, and $\mathrm{H}_{2} \mathrm{O}_{2}$. Decreases in $\Delta^{17} \mathrm{O}\left(\mathrm{nss}-\mathrm{SO}_{4}^{2-}\right)$ and $\Delta^{17} \mathrm{O}\left(\mathrm{NO}_{3}^{-}\right)$values are caused by the combined effects of the decrease in the ozone concentration and the decrease in the transfer efficiency of $\Delta^{17} \mathrm{O}\left(\mathrm{O}_{3}\right)$ to the final products. Thus, the changes in relative concentrations of $\mathrm{O}_{3}$ vs. $\mathrm{HO}_{x}, \mathrm{RO}_{x}$, and $\mathrm{H}_{2} \mathrm{O}_{2}$, along with the changes in sunlight level, are the main factors controlling the seasonal variations of $\Delta^{17} \mathrm{O}\left(\mathrm{nss}-\mathrm{SO}_{4}^{2-}\right)$ and $\Delta^{17} \mathrm{O}\left(\mathrm{NO}_{3}^{-}\right)$values.

A similar seasonal variation in $\Delta^{17} \mathrm{O}\left(\mathrm{nss}-\mathrm{SO}_{4}^{2-}\right)$ values has been observed at Dome $\mathrm{C}$, an inland Antarctic site (HillFalkenthal et al., 2013). However, the $\Delta^{17} \mathrm{O}\left(\mathrm{nss}-\mathrm{SO}_{4}^{2-}\right)$ values observed at Dome $\mathrm{C}$ significantly declined in July and August, in contrast to our observations that showed only a single significant decline in $\Delta^{17} \mathrm{O}\left(\mathrm{nss}-\mathrm{SO}_{4}^{2-}\right)$ values during the period of $18-25$ July. This low $\Delta^{17} \mathrm{O}\left(\mathrm{nss}-\mathrm{SO}_{4}^{2-}\right)$ sample is also characterized by high nss- $\mathrm{SO}_{4}^{2-}$ concentration (Fig. 2a). We don't have any evidence of contamination from station activities or laboratory works. The preliminary result of the sulfur isotope analysis of sulfate in the same sample, showing a $\delta^{34} \mathrm{~S}$ value of $17.6 \%$ (to be published), suggests 
that this sulfate results from marine biogenic sulfur (i.e., DMS) which possesses $\delta^{34} \mathrm{~S}$ values ranging $16-20 \%$ (Oduro et al., 2012; Amrani et al., 2013). However, the results of the back trajectory analyses show that DDU was under a continental outflow condition over this period, as well as throughout July (Fig. 3). It is hence difficult to identify the origin of this low $\Delta^{17} \mathrm{O}\left(\mathrm{nss}-\mathrm{SO}_{4}^{2-}\right.$ ) value during $18-25$ July. Nevertheless, this point does not change the interpretation that $\Delta^{17} \mathrm{O}\left(\mathrm{nss}-\mathrm{SO}_{4}^{2-}\right)$ values are generally lower in summer and higher in winter. Thus, this sample was excluded from consideration for the following discussion and does not impair our further interpretation.

For sulfate, the relative contribution of $\mathrm{O}_{3}$ oxidation for sulfate formation $\left(f\left(\mathrm{nss}-\mathrm{SO}_{4}^{2-}\right)_{\mathrm{O}_{3}}\right)$ was calculated. Since positive $\Delta^{17} \mathrm{O}$ (nss-SO $\mathrm{SO}_{4}^{2-}$ ) values result from only $\mathrm{H}_{2} \mathrm{O}_{2}$ and $\mathrm{O}_{3}$ oxidation and the other pathways result in $\Delta^{17} \mathrm{O}$ (nss$\mathrm{SO}_{4}^{2-}$ ) of approximately $0 \%$, we calculated the maximum and the minimum $f$ (nss- $\mathrm{SO}_{4}^{2-}$ ) Oे $_{3}$ by assuming no contribution of $\mathrm{H}_{2} \mathrm{O}_{2}$ oxidation and assuming the contribution from only $\mathrm{H}_{2} \mathrm{O}_{2}$ and $\mathrm{O}_{3}$ oxidation, respectively, using the simple mass balance equation. Consequently, the mean summer (January, February, and December) $\Delta^{17} \mathrm{O}\left(\mathrm{nss}-\mathrm{SO}_{4}^{2-}\right.$ ) value of $1.2 \%$ corresponds to an $f$ (nss- $\left.\mathrm{SO}_{4}^{2-}\right)_{\mathrm{O}_{3}}$ of $0.07-0.18$, whereas the mean winter (June-August) $\Delta^{17} \mathrm{O}\left(\mathrm{nss}-\mathrm{SO}_{4}^{2-}\right.$ ) value of $2.4 \%$ corresponds to an $f\left(n s s-\mathrm{SO}_{4}^{2-}\right)_{\mathrm{O}_{3}}$ of $0.28-$ 0.37 . The relative contribution of $\mathrm{O}_{3}$ oxidation is thus 2- to 4-fold higher in winter than in summer. However, it is important to mention that DMS levels are quite low at DDU in winter (Preunkert et al., 2007); the sulfate collected at DDU is likely produced at a lower latitude region under more sunlight. Thus, the observed $\Delta^{17} \mathrm{O}\left(\mathrm{nss}-\mathrm{SO}_{4}^{2-}\right)$ values in winter may not solely reflect oxidation chemistry in the local atmosphere at DDU. The sulfur sources need to be constrained for the interpretation of winter data. Also for nitrate, it is believed that during Antarctic winter period the atmospheric nitrate results mainly from the deposition of polar stratospheric clouds (Santacesaria et al., 2001; Savarino et al., 2007) and $\Delta^{17} \mathrm{O}\left(\mathrm{NO}_{3}^{-}\right)$values are not representative of the oxidation chemistry of the atmosphere at this site. On the other hand, a mean summer $\Delta^{17} \mathrm{O}\left(\mathrm{NO}_{3}^{-}\right)$value of $27.1 \%$ requires the contribution of the $\mathrm{NO}_{2}+\mathrm{OH}$ pathway $\left(f\left(\mathrm{NO}_{3}^{-}\right)_{\mathrm{OH}}\right)$. Therefore, for the $f\left(\mathrm{NO}_{3}^{-}\right)_{\mathrm{OH}}$ value, the maximum was calculated by assuming no contribution of $\mathrm{N}_{2} \mathrm{O}_{5}$ hydrolysis, whereas the minimum was calculated no contribution of $\mathrm{NO}_{3}+\mathrm{RH}$ and $\mathrm{BrONO}_{2}$ hydrolysis pathways. As a result, the $f\left(\mathrm{NO}_{3}^{-}\right)_{\mathrm{OH}}$ value corresponding to the summer $\Delta^{17} \mathrm{O}\left(\mathrm{NO}_{3}^{-}\right)$value of $27.1 \%$ is expected to range $0.28-0.52$. However, this is in contradiction to an expectation that the termination reaction is only the $\mathrm{NO}_{2}+\mathrm{OH}$ pathway under permanent sunlight. For further constraints on oxidation chemistry, a coupled stratosphere-troposphere chemical transport model will be necessary, which is beyond the scope of this paper.

\subsection{Sensitivity of sulfate and nitrate $\Delta^{17} \mathrm{O}$ values to the ozone mixing ratio}

To examine the response of $\Delta^{17} \mathrm{O}$ values to the changes in oxidant concentration, we compared $\Delta^{17} \mathrm{O}\left(\mathrm{nss}-\mathrm{SO}_{4}^{2-}\right)$ and $\Delta^{17} \mathrm{O}\left(\mathrm{NO}_{3}^{-}\right)$values to the ozone mixing ratio (Fig. 4), which was only one oxidant observed in year-round scale at the same time. In Fig. $4, \Delta^{17} \mathrm{O}$ (nss-SO ${ }_{4}^{2-}$ ) and $\Delta^{17} \mathrm{O}\left(\mathrm{NO}_{3}^{-}\right)$values are generally covaried with ozone mixing ratios, suggesting that a change in the ozone mixing ratio is one of the main factors controlling $\Delta^{17} \mathrm{O}\left(\mathrm{nss}-\mathrm{SO}_{4}^{2-}\right)$ and $\Delta^{17} \mathrm{O}\left(\mathrm{NO}_{3}^{-}\right)$values. Note that as mentioned in Sect. 4.2, in winter, $\Delta^{17} \mathrm{O}$ (nss$\left.\mathrm{SO}_{4}^{2-}\right)$ and $\Delta^{17} \mathrm{O}\left(\mathrm{NO}_{3}^{-}\right)$values are not directly linked to the ozone mixing ratios at DDU.

Excluding winter data (June to August), the regression lines for sulfate and nitrate have slopes, intercepts, and correlation coefficients $\left(R^{2}\right)$ of $0.07,-0.01$, and 0.50 , and 0.55 , 18.2, and 0.80, respectively (Fig. 4). These slopes indicate how sensitive $\Delta^{17} \mathrm{O}\left(\mathrm{nss}-\mathrm{SO}_{4}^{2-}\right)$ and $\Delta^{17} \mathrm{O}\left(\mathrm{NO}_{3}^{-}\right)$values are to ozone mixing ratios. Meanwhile, the intercepts indicate $\Delta^{17} \mathrm{O}\left(\mathrm{nss}-\mathrm{SO}_{4}^{2-}\right)$ and $\Delta^{17} \mathrm{O}\left(\mathrm{NO}_{3}^{-}\right)$values when assuming ozone was not involved in the oxidation of $\mathrm{SO}_{2}$ and $\mathrm{NO}_{2}$. If this was true, it would imply that the seasonal cycles of $\Delta^{17} \mathrm{O}\left(\mathrm{nss}-\mathrm{SO}_{4}^{2-}\right)$ and $\Delta^{17} \mathrm{O}\left(\mathrm{NO}_{3}^{-}\right)$were largely controlled by the last stage of oxidation and not by the $\Delta^{17} \mathrm{O}$ values of their precursors. In the case of sulfate, this is likely to be true, given that $\Delta^{17} \mathrm{O}\left(\mathrm{SO}_{2}\right)=0 \%$ year-round, because of oxygen isotopic exchange between $\mathrm{SO}_{2}$ and water vapor. Therefore, the intercept for sulfate of approximately $0 \%$ is consistent with $\Delta^{17} \mathrm{O}\left(\mathrm{nss}-\mathrm{SO}_{4}^{2-}\right)$ values for sulfate produced via the $\mathrm{SO}_{2}+\mathrm{OH}$ pathway. Meanwhile, the intercept of approximately $18 \%$ for nitrate (Fig. 4b) corresponds to a $\Delta^{17} \mathrm{O}\left(\mathrm{NO}_{2}\right)$ value of $27 \%$, assuming all nitrate is produced via the $\mathrm{NO}_{2}+\mathrm{OH}$ pathway. This $\Delta^{17} \mathrm{O}\left(\mathrm{NO}_{2}\right)$ value is in a good agreement with the value of $26 \%$ calculated for conditions at $80^{\circ} \mathrm{N}$ under the assumption that $\Delta{ }^{17} \mathrm{O}(\mathrm{OH})=0 \%$ o (Morin et al., 2011). Using the calculation processes of Morin et al. (2011), we calculated $\Delta{ }^{17} \mathrm{O}\left(\mathrm{NO}_{2}\right)$ to be $26.5 \%$, consistent with the intercept value. In this calculation, we employed DDU conditions for summer, with a mean temperature of about $0{ }^{\circ} \mathrm{C}, \Delta \Delta^{17} \mathrm{O}\left(\mathrm{O}_{3}\right)=26 \%$ and mixing ratios of $\mathrm{O}_{3}$ and $\mathrm{RO}_{2}$ of $5.6 \times 10^{11}$ molecules $\mathrm{cm}^{-3}$ and $3.3 \times 10^{8}$ molecules $\mathrm{cm}^{-3}$, respectively (Legrand et al., 2009; Kukui et al., 2012). Thus, the plot of $\Delta^{17} \mathrm{O}\left(\mathrm{NO}_{3}^{-}\right)$values as a function of ozone mixing ratios has the potential to be used for estimating $\Delta^{17} \mathrm{O}\left(\mathrm{NO}_{2}\right)$ values, which have never been measured.

The sensitivity of $\Delta^{17} \mathrm{O}\left(\mathrm{nss}-\mathrm{SO}_{4}^{2-}\right)$ values to ozone mixing ratios in spring (September to November) seems to be lower than in fall (March to May) (Fig. 4). Fixing the intercept to -0.01 , the slopes between the $\Delta^{17} \mathrm{O}\left(\mathrm{nss}-\mathrm{SO}_{4}^{2-}\right)$ values and ozone mixing ratios for spring and fall were $0.063 \pm 0.004$ and $0.084 \pm 0.005$ respectively, showing a clear difference over their range of deviation. In contrast 

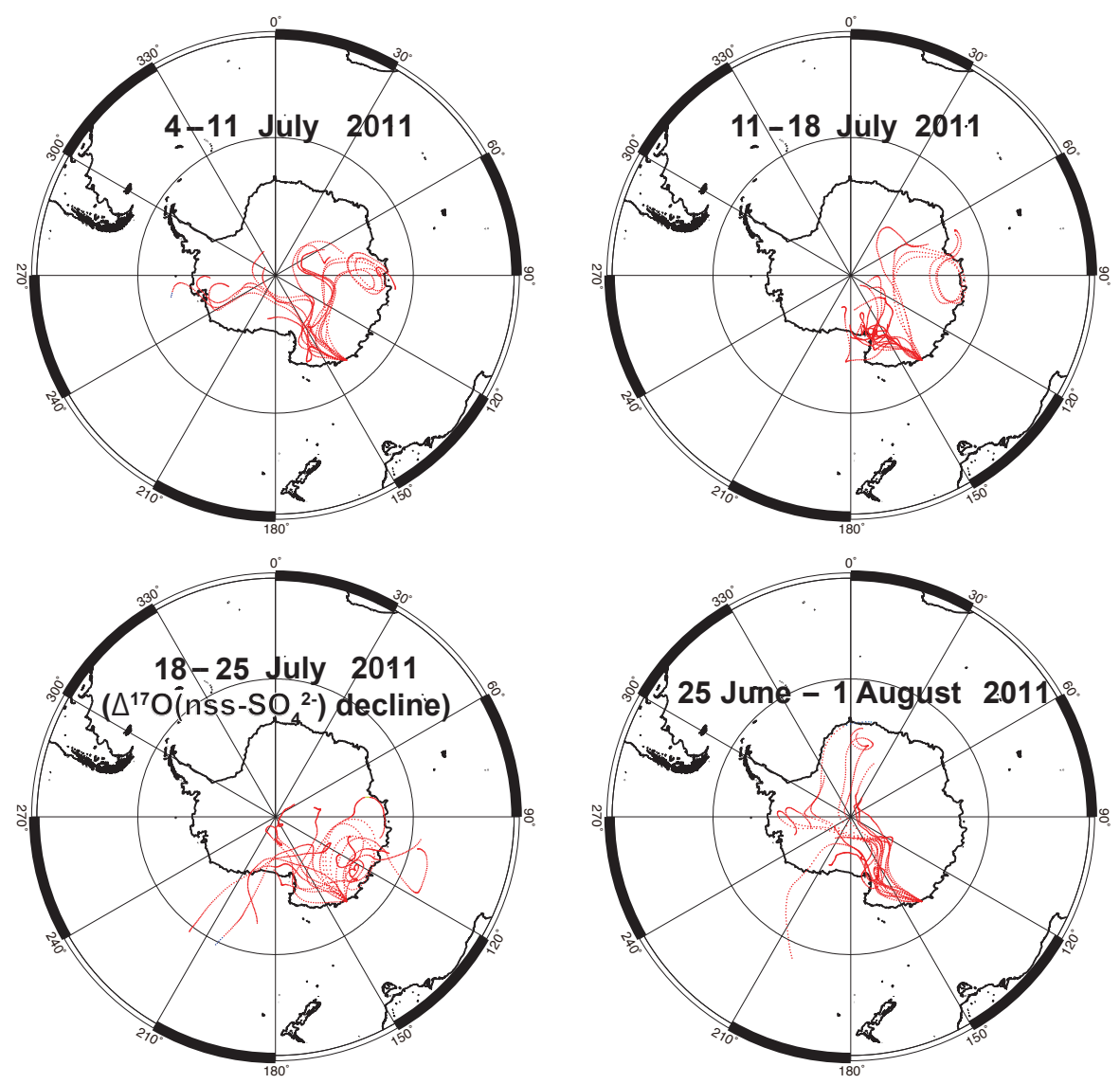

Figure 3. Air mass pathways arriving at Dumont d'Urville Station during sampling periods in July 2011.

to $\Delta^{17} \mathrm{O}\left(\mathrm{nss}-\mathrm{SO}_{4}^{2-}\right)$ values, the slopes between $\Delta^{17} \mathrm{O}\left(\mathrm{NO}_{3}^{-}\right)$ values and the ozone mixing ratios for an intercept fixed to 18.2 show of a less difference between spring and fall, with values of $0.54 \pm 0.02$ and $0.57 \pm 0.01$, respectively. However, $\Delta^{17} \mathrm{O}\left(\mathrm{nss}-\mathrm{SO}_{4}^{2-}\right)$ is also sensitive to $\mathrm{HO}_{x}, \mathrm{RO}_{x}$, and $\mathrm{H}_{2} \mathrm{O}_{2}$. If the relative abundance of $\mathrm{O}_{3}$ vs. $\mathrm{HO}_{x}, \mathrm{RO}_{x}$, and $\mathrm{H}_{2} \mathrm{O}_{2}$ are only regulated by changes in solar irradiation as discussed in Sect. 4.2, then the slopes between the $\Delta^{17} \mathrm{O}$ values for sulfate and nitrate against ozone mixing ratios should be the same for spring and fall. The different slopes observed for sulfate in spring and fall indicate the effects of various oxidation processes, with decreasing $\Delta^{17} \mathrm{O}\left(\mathrm{nss}-\mathrm{SO}_{4}^{2-}\right)$ in spring and/or increasing $\Delta^{17} \mathrm{O}\left(\mathrm{nss}-\mathrm{SO}_{4}^{2-}\right)$ in fall. There are several processes that could explain such a spring/fall difference.

One possible explanation involves the influence of $\mathrm{NO}_{x}$ emissions from snowpack covering the East Antarctic plateau (Davis et al., 2001; Crawford et al., 2001; Chen et al., 2001). The Antarctic atmosphere is strongly affected by $\mathrm{NO}_{x}$ emissions from snowpack, starting at the beginning of spring with the return of sunlight. These snow $\mathrm{NO}_{x}$ emissions subsequently enhance both $\mathrm{O}_{3}$ and $\mathrm{OH}$ productions, with $\mathrm{OH}$ being in greater proportion than $\mathrm{O}_{3}$. This is par- ticularly true at DDU in summer, where katabatic air from the East Antarctic plateau causes the ozone mixing ratio to be in the range of 10-40 ppbv (Legrand et al., 2009, 2016a), with a mean $\mathrm{OH}$ concentration of $2.1 \times 10^{6}$ molecules $\mathrm{cm}^{-3}$ (Kukui et al., 2012). In contrast, Palmer Station is exposed to oceanic air, producing ozone mixing ratios within the range of 9-20 ppbv with a mean $\mathrm{OH}$ concentration of about $1.0 \times 10^{5}$ molecules $\mathrm{cm}^{-3}$ (Jefferson et al., 1998). These observations suggest that $\mathrm{NO}_{x}$ emissions increase oxidants at DDU about 2-fold for $\mathrm{O}_{3}$ and more than 10-fold for $\mathrm{OH}$ compared to Palmer Station. Chemical transport models over the Antarctic continent show that $\mathrm{NO}_{x}$ emitted from snow during summer increase $\mathrm{O}_{3}$ and $\mathrm{OH}$ by a factor of 2 and 7 , respectively, compared to estimations not including snow $\mathrm{NO}_{x}$ emissions (Zatko et al., 2016). Additionally, ${ }^{15} \mathrm{~N}$ depletion in nitrate starts from the beginning of September (See Supplement), which is consistent with previous measurement at DDU (Savarino et al., 2007), and supports the possibility that snow $\mathrm{NO}_{x}$ emission happens in early spring at DDU. Thus, $\mathrm{OH}$ production is enhanced more efficiently than $\mathrm{O}_{3}$ production in spring by snow $\mathrm{NO}_{x}$ emission, possibly resulting in lower $\Delta^{17} \mathrm{O}\left(\right.$ nss- $\left.\mathrm{SO}_{4}^{2-}\right)$ spring values.

Another possible explanation is that hypohalous acids $\left(\mathrm{HOX}=\mathrm{HOCl}\right.$ and $\mathrm{HOBr}$ ) act as important oxidants of $\mathrm{SO}_{2}$ 

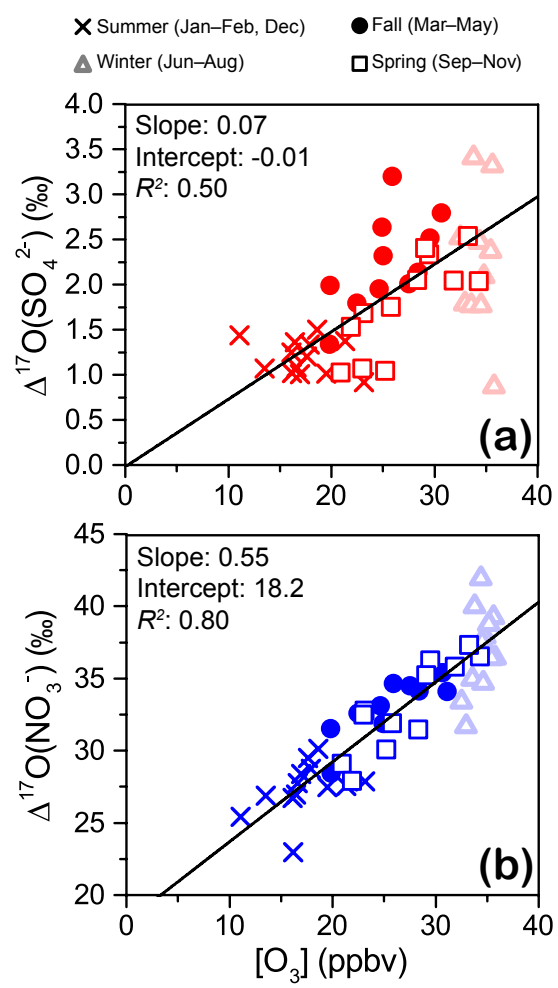

Figure 4. $\Delta^{17} \mathrm{O}$ values of (a) sulfate and (b) nitrate as a function of ozone mixing ratios $\left[\mathrm{O}_{3}\right]$. Winter values were not taken into account in the calculation of slopes and intercepts.

via the aqueous phase Reactions (R16) and (R17) in the marine boundary layer (Fogelman et al., 1989; von Glasow et al., 2002):

$\mathrm{HOX}+\mathrm{SO}_{3}^{2-} \rightarrow \mathrm{OH}^{-}+\mathrm{XSO}_{3}^{2-}$,

$\mathrm{XSO}_{3}^{2-}+\mathrm{H}_{2} \mathrm{O} \rightarrow \mathrm{SO}_{4}^{2-}+\mathrm{X}^{-}+2 \mathrm{H}^{+}$.

This reaction is expected to produce sulfate with $\Delta{ }^{17} \mathrm{O}=0 \%$ as all oxygen atoms of sulfate originate from water (Fogelman et al., 1989; Troy and Margerum, 1991: Yiin and Margerum, 1988), leading to lower $\Delta^{17} \mathrm{O}$ (nss$\mathrm{SO}_{4}^{2-}$ ) values in the atmosphere. Indeed, unexpectedly low $\Delta^{17} \mathrm{O}\left(\mathrm{nss}-\mathrm{SO}_{4}^{2-}\right)$ values have been observed in marine aerosols, which is possibly explained by a contribution of HOX oxidation of $33-50 \%$ to total sulfate production in the marine boundary layer (Chen et al., 2016). Chen et al. (2016) estimated that a minimum concentration of gaseous HOX of 0.1 pptv could account for half of the sulfate production in the marine boundary layer. At DDU, yearround observations of gaseous inorganic bromine species $\left(\left[\mathrm{Br}_{y}^{*}\right]=[\mathrm{HBr}]+[\mathrm{HOBr}]+0.9\left[\mathrm{Br}_{2}\right]+0.4[\mathrm{BrO}]+\left[\mathrm{BrNO}_{2}\right]\right.$ $\left.+\left[\mathrm{BrONO}_{2}\right]+[\mathrm{Br}]\right)$ revealed that maximum concentrations are observed in September, with values of $13.0 \pm 6.5 \mathrm{ng} \mathrm{m}^{-3}$ ( $3.6 \mathrm{pptv}$ ) (Legrand et al., 2016b). Even if only one third of the $\mathrm{Br}_{y}^{*}$ corresponds to $\mathrm{HOBr}$, as estimated using the model calculations by Legrand et al. (2016b) under summer conditions, then it is expected that HOX at DDU in spring is $>1$ pptv; thus, HOX could play a significant role in sulfate production in spring. Likewise, $\mathrm{Br}_{y}^{*}$ concentration at DDU is at minimum in May, with values of $3.4 \pm 1.0 \mathrm{ng} \mathrm{m}^{-3}$ (Legrand et al., 2016b) corresponding to less than one third of spring values. This would lead to a lower contribution of HOX to sulfate production in fall compared with spring. Hence, sulfate production via aqueous oxidation by HOX may explain the lower $\Delta^{17} \mathrm{O}\left(\mathrm{SO}_{4}^{2-}\right)$ values in spring relative to fall.

A change in the $\mathrm{pH}$ of the aqueous phase on the aerosol surfaces may also explain the spring/fall difference in $\Delta^{17} \mathrm{O}$ (nss-SO ${ }_{4}^{2-}$ ). Given that $\mathrm{SO}_{2}$ oxidation by ozone in the aqueous phase is favored at high $\mathrm{pH}(>5.5)$ (Seinfeld and Pandis, 2006), if the $\mathrm{pH}$ of aerosol droplets is higher in fall than in spring, then the relative importance of the $\mathrm{SO}_{2}+\mathrm{O}_{3}$ reaction resulting in higher $\Delta^{17} \mathrm{O}$ values would increase in fall. However, ion concentration analyses of aerosols collected at DDU exhibited higher alkalinity in spring than in fall (Jourdain and Legrand, 2002; Legrand et al., 2016b), which is inconsistent with this explanation. Hence, this process can be excluded from further consideration.

It should be noted that a smaller difference was observed between spring and fall $\Delta^{17} \mathrm{O}\left(\mathrm{NO}_{3}^{-}\right)$values, which would also be affected by the above two processes. Snow $\mathrm{NO}_{x}$ emission would decrease $\Delta^{17} \mathrm{O}\left(\mathrm{NO}_{3}^{-}\right)$through depression of the contribution of $\mathrm{O}_{3}$ oxidation relative to the other oxidation pathways by $\mathrm{HO}_{x}$ and $\mathrm{RO}_{x}$, while halogen chemistry would lead to high $\Delta^{17} \mathrm{O}\left(\mathrm{NO}_{3}^{-}\right)$values through an oxygen atom transfer from $\mathrm{O}_{3}$ to $\mathrm{BrO}$ and consequently to nitrate (Morin et al., 2007; Savarino et al., 2013). Although it is difficult to identify the precise processes involved, observations of $\Delta^{17} \mathrm{O}\left(\mathrm{nss}-\mathrm{SO}_{4}^{2-}\right)$ and $\Delta^{17} \mathrm{O}\left(\mathrm{NO}_{3}^{-}\right)$values at an inland site (e.g., Concordia Station) would enable us to determine which process causes the spring/fall difference in the oxidation chemistry in the DDU atmosphere. If snow $\mathrm{NO}_{x}$ emission is the source of low $\Delta^{17} \mathrm{O}\left(\mathrm{nss}^{\left.-\mathrm{SO}_{4}^{2-}\right)}\right.$ at DDU in spring, then $\Delta^{17} \mathrm{O}\left(\mathrm{nss}-\mathrm{SO}_{4}^{2-}\right)$ and $\Delta^{17} \mathrm{O}\left(\mathrm{NO}_{3}^{-}\right)$at an inland site would also exhibit lower values in spring than in fall.

\subsection{Air mass origin analysis}

Using observations of several oxidants at DDU and Concordia Station (e.g., Legrand et al., 2009, 2016a; Kukui et al., 2012, 2014; Grilli et al., 2013), it has been suggested that the oxidative capacity of the atmosphere at DDU is influenced by air masses transported from the East Antarctic plateau during katabatic wind outflows. The $\mathrm{NO}_{x}$ emission from snowpack in inland Antarctica stimulates the ozone, $\mathrm{HO}_{x}, \mathrm{RO}_{x}$, and $\mathrm{H}_{2} \mathrm{O}_{2}$ production through the enhanced $\mathrm{NO}_{x}$ cycle. Thus, the atmosphere at DDU is enriched in all of those photochemical oxidants when air masses are from inland regions, compared to when air masses are from the ocean (Legrand et al., 2009). Therefore, we expected that $\Delta^{17} \mathrm{O}$ values for sulfate and nitrate also depend on air mass origin. 

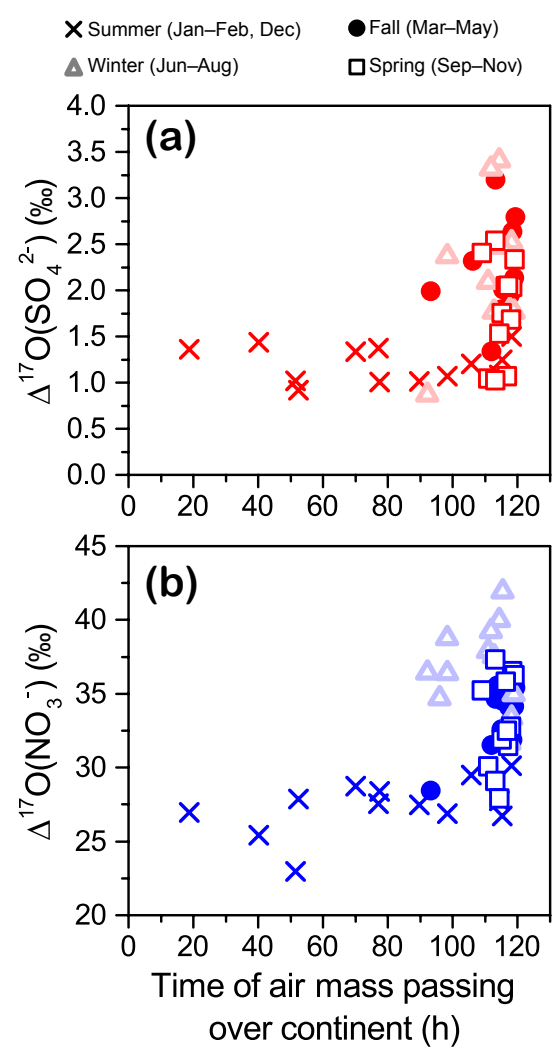

Figure 5. Relationship between $\Delta^{17} \mathrm{O}$ values of (a) sulfate and (b) nitrate with the time taken for air masses to pass over the Antarctic continent (i.e., air mass contact time with surface snow).

In Fig. 5, the $\Delta^{17} \mathrm{O}$ values for sulfate and nitrate are given as a function of the time that air masses were over the continent during the five days' travel prior to arriving at DDU. Summer data show that the contact times of air masses with the continent varied between 20 and 120 h (i.e., continental air and oceanic air were well mixed). Similarly, their $\Delta^{17} \mathrm{O}$ values show insignificant variation, having low values of around 1 and $25 \%$ for sulfate and nitrate, respectively. This trend reflects two different phenomena: decreased $\Delta^{17} \mathrm{O}$ values in summer because of the high contribution of photooxidants to atmospheric chemistry and increased import of oceanic air. In contrast, plots for other seasons show that the $\Delta{ }^{17} \mathrm{O}$ values exhibit high variation, although most of the air masses originate from the continent. It is important to note that this non-correlation does not mean that there is no link between $\Delta{ }^{17} \mathrm{O}$ values and air mass origin. The influence of air mass transport on oxidative capacity has been demonstrated in daily observations of oxidants (e.g., Legrand et al., 2009). Given that air masses at this site are from a variety of directions and are mixed together, this makes the interpretation of weekly averaged analyses more complicated. Hence, a non-significant correlation between $\Delta{ }^{17} \mathrm{O}$ values and air mass origin in weekly data could reflect a real lack of correlation or a too broad time resolution for these data.

\section{Summary}

To develop an understanding of the factors influencing $\Delta^{17} \mathrm{O}$ values of atmospheric sulfate and nitrate, seasonal variations of $\Delta^{17} \mathrm{O}$ values of atmospheric sulfate, nitrate, and ozone were analyzed using the aerosol samples collected at DDU throughout 2011. Both $\Delta^{17} \mathrm{O}\left(\mathrm{nss}-\mathrm{SO}_{4}^{2-}\right)$ and $\Delta^{17} \mathrm{O}\left(\mathrm{NO}_{3}^{-}\right)$ values exhibited clear seasonal variations, with summer minima and winter maxima. In contrast, $\Delta^{17} \mathrm{O}$ values of ozone showed limited variability throughout the year, indicating that $\Delta^{17} \mathrm{O}\left(\mathrm{O}_{3}\right)$ values do not significantly influence summer/winter trends in $\Delta^{17} \mathrm{O}\left(\mathrm{nss}-\mathrm{SO}_{4}^{2-}\right)$ and $\Delta^{17} \mathrm{O}\left(\mathrm{NO}_{3}^{-}\right)$ values. We hence, for the first time, demonstrated that $\Delta^{17} \mathrm{O}\left(\mathrm{nss}-\mathrm{SO}_{4}^{2-}\right)$ and $\Delta^{17} \mathrm{O}\left(\mathrm{NO}_{3}^{-}\right)$values are the direct result of the oxidation chemistry of their precursors.

The summer/winter trends of $\Delta^{17} \mathrm{O}\left(\mathrm{nss}-\mathrm{SO}_{4}^{2-}\right)$ and $\Delta^{17} \mathrm{O}\left(\mathrm{NO}_{3}^{-}\right)$values are likely to reflect sunlight-driven changes in the relative importance of oxidation pathways; oxidation by $\mathrm{HO}_{x}, \mathrm{RO}_{x}$, and $\mathrm{H}_{2} \mathrm{O}_{2}$ is increased during summer when the solar radiation enhances the production of those oxidants, whereas the relative contribution of the oxidation reaction transferring oxygen atoms of $\mathrm{O}_{3}$ to sulfate and nitrate is increased during winter period. Interestingly, by comparing $\Delta^{17} \mathrm{O}\left(\mathrm{nss}-\mathrm{SO}_{4}^{2-}\right)$ and $\Delta^{17} \mathrm{O}\left(\mathrm{NO}_{3}^{-}\right)$values to ozone mixing ratios, we found that the $\Delta^{17} \mathrm{O}\left(\mathrm{nss}-\mathrm{SO}_{4}^{2-}\right.$ ) values in the spring months were lower than in fall months despite similar ozone levels for spring and fall, whereas there was no clear difference between $\Delta^{17} \mathrm{O}\left(\mathrm{NO}_{3}^{-}\right)$values. Possible explanations for the spring/fall differences for sulfate include (i) the low relative contribution of $\mathrm{O}_{3}$ oxidation in spring induced by reactive nitrogen emissions from snowpack at inland sites being transported to coastal sites and (ii) the effects of $\mathrm{SO}_{2}$ oxidation by hypohalous acids ( $\mathrm{HOCl}$ and $\mathrm{HOBr}$ ) enhanced in spring by the interaction of sea salt particles with photo-oxidants. Further observations of $\Delta^{17} \mathrm{O}\left(\mathrm{nss}-\mathrm{SO}_{4}^{2-}\right)$ and $\Delta^{17} \mathrm{O}\left(\mathrm{NO}_{3}^{-}\right)$in aerosols collected at Antarctic inland sites will help us identify the processes causing such different sulfate and nitrate formation in spring and fall. Nevertheless, the dataset of this study can be dedicated to atmospheric chemical transport models to improve the constraints on unique local oxidation chemistry at DDU.

Data availability. The data used for the figures and the interpretations are shown in Supplement.

\section{The Supplement related to this article is available online at doi:10.5194/acp-17-3713-2017-supplement.}

Author contributions. S. Ishino, S. Hattori, and J. Savarino designed the research. M. Legrand, B. Jourdain, and S. Preunkert provided qualified complementary data, organized the Antarctic field campaign, and collected samples. S. Ishino, S. Hattori, J. Savarino, A. Barbero, and N. Caillon performed experiments. S. Ishino, 
S. Hattori, J. Savarino, K. Kuribayashi, and N. Yoshida analyzed data. S. Ishino, S. Hattori, and J. Savarino prepared the manuscript, with contributions from all other co-authors.

Competing interests. The authors declare that they have no conflict of interest.

Acknowledgements. Financial support and field supplies for winter and summer campaigns at DDU were provided by the Institut Paul Emile Victor (IPEV) from Program 414, program 1011 (SUNITEDC), and the French Environmental Observation Service CESOA (Etude du cycle atmosphérique du Soufre en relation avec le climat aux moyennes et hautes latitudes Sud; http://www-lgge.obs.ujf-grenoble.fr/CESOA/donnees/Cesoa/) dedicated to the study of the sulfur cycle at middle and high southern latitudes, and supported by the National Centre for Scientific Research (CNRS) Institute for Earth Sciences and Astronomy (INSU). This work is also supported by a Grant-in-Aid for Scientific Research (S) (23224013) from the Ministry of Education, Culture, Sports, Science and Technology (MEXT), Japan, a Grant-in-Aid for Young Scientist (A) (16H05884) of MEXT, Japan, and by a research fund from Asahi Group Foundation. S. Hattori, S. Ishino, and N. Yoshida are supported by a Japan-France Research Cooperative Program (SAKURA and CNRS) of MEXT, Japan. J. Savarino and N. Caillon thank the CNRS/INSU (PRC program 207394) and the PH-SAKURA program of the French Embassy in Japan (project 31897PM) for financial support for this collaboration. This work has been supported by a grant from Labex OSUG@2020 (Investissements d'avenir - ANR10 LABX56). S. Ishino thanks the Academy for Co-creative Education of Environment and Energy Science for financial support. We are grateful to Basile de Fleurian who carried out winter sampling at DDU in 2011. The authors gratefully acknowledge Erwann Vince of the Laboratoire d'étude des Transferts en Hydrologie \& Environnement for preparation of the bacterial cultures used for nitrate and ozone isotope analyses. Meteo France are acknowledged for providing meteorological data. Lars Kaleschke and his team members provided sea ice data. We also acknowledge the Air Resources Laboratory (ARL) for the use of their HYSPLIT transport and dispersion model available on the READY Web site (http://www.arl.noaa.gov/ready.html). Finally, we acknowledge two anonymous referees for their fruitful comments.

Edited by: E. Harris

Reviewed by: two anonymous referees

\section{References}

Alexander, B., Hastings, M. G., Allman, D. J., Dachs, J., Thornton, J. A., and Kunasek, S. A.: Quantifying atmospheric nitrate formation pathways based on a global model of the oxygen isotopic composition $\left(\Delta^{17} \mathrm{O}\right)$ of atmospheric nitrate, Atmos. Chem. Phys., 9, 5043-5056, doi:10.5194/acp-9-5043-2009, 2009.

Amrani, A., Said-Ahmad, W., Shaked, Y., and Kiene, R. P.: Sulfur isotope homogeneity of oceanic DMSP and DMS, P. Natl. Acad. Sci. USA, 110, 18413-18418, 2013.
Barkan, E. and Luz, B.: High-precision measurements of ${ }^{17} \mathrm{O} /{ }^{16} \mathrm{O}$ and ${ }^{18} \mathrm{O} /{ }^{16} \mathrm{O}$ ratios in $\mathrm{O}_{2}$ and $\mathrm{O}_{2} / \mathrm{Ar}$ ratio, Rapid Commun. Mass Sp., 17, 2804-2814, 2003.

Barkan, E. and Luz, B.: High-precision measurements of ${ }^{17} \mathrm{O} /{ }^{16} \mathrm{O}$ and ${ }^{18} \mathrm{O} /{ }^{16} \mathrm{O}$ ratios in $\mathrm{H}_{2} \mathrm{O}$, Rapid Commun. Mass Sp., 19, 3737-3742, 2005.

Bhattacharya, S. K., Pandey, A., and Savarino, J.: Determination of intramolecular isotope distribution of ozone by oxidation reaction with silver metal, J. Geophys. Res., 113, D03303, doi:10.1029/2006jd008309, 2008.

Casciotti, K. L., Sigman, D. M., Galanter Hastings, M., Böhlke, J. K., and Hilkert, A.: Measurement of the oxygen isotopic composition of nitrate in seawater and freshwater using the denitrifier method, Anal. Chem., 74, 4905-4912, 2002.

Chen, G., Davis, D., Crawford, J., Nowak, J. B., Eisele, F., Mauldin, R. L., Tanner, D., Buhr, M., Shetter, R., Lefer, B., Arimoto, R., Hogan, A., and Blake, D.: An investigation of South Pole $\mathrm{HO}_{x}$ chemistry: comparison of model results with ISCAT observations, Geophys. Res. Lett., 28, 3633-3636, 2001.

Chen, Q., Geng, L., Schmidt, J. A., Xie, Z., Kang, H., Dachs, J., Cole-Dai, J., Schauer, A. J., Camp, M. G., and Alexander, B.: Isotopic constraints on the role of hypohalous acids in sulfate aerosol formation in the remote marine boundary layer, Atmos. Chem. Phys., 16, 11433-11450, doi:10.5194/acp-1611433-2016, 2016.

Crawford, J. H., Davis, D. D., Chen, G., Buhr, M., Oltmans, S., Weller, R., Mauldin, L., Eisele, F., Shetter, R., Lefer, B., Arimoto, R., and Hogan, A.: Evidence for photochemical production of ozone at the South Pole surface, Geophys. Res. Lett., 28, 36413644, 2001.

Davis, D., Nowak, J. B., Chen, G., Buhr, M., Arimoto, R., Hogan, A., Eisele, F., Mauldin, L., Tanner, D., Shetter, R., Lefer, B., and McMurry, P.: Unexpected high levels of NO observed at South Pole, Geophys. Res. Lett., 28, 3625-3628, 2001.

Erbland, J., Vicars, W. C., Savarino, J., Morin, S., Frey, M. M., Frosini, D., Vince, E., and Martins, J. M. F.: Air-snow transfer of nitrate on the East Antarctic Plateau - Part 1: Isotopic evidence for a photolytically driven dynamic equilibrium in summer, Atmos. Chem. Phys., 13, 6403-6419, doi:10.5194/acp-136403-2013, 2013.

Feitcher, J., Kjellstrom, E., Rodhe, H., Dentener, F., Lelieveld, J., and Roelofs, G. J.: Simulation of the tropospheric sulfur cycle in a global climate model, Atmos. Environ., 30, 1693-1707, 1996.

Fogelman, K. D., Walker, D. M., and Margerum, D. W.: Nonmetal redox kinetics: hypochlorite and hypochlorous acid reactions with sulfite, Inorg. Chem., 28, 986-993, doi:10.1021/ic00305a002, 1989.

Frey, M. M., Savarino, J., Morin, S., Erbland, J., and Martins, J. M. F.: Photolysis imprint in the nitrate stable isotope signal in snow and atmosphere of East Antarctica and implications for reactive nitrogen cycling, Atmos. Chem. Phys., 9, 8681-8696, doi:10.5194/acp-9-8681-2009, 2009.

Frey, M. M., Roscoe, H. K., Kukui, A., Savarino, J., France, J. L., King, M. D., Legrand, M., and Preunkert, S.: Atmospheric nitrogen oxides ( $\mathrm{NO}$ and $\mathrm{NO}_{2}$ ) at Dome C, East Antarctica, during the OPALE campaign, Atmos. Chem. Phys., 15, 7859-7875, doi:10.5194/acp-15-7859-2015, 2015.

Gao, Y. Q. and Marcus, R. A.: Strange and unconventional isotope effects in ozone formation, Science, 293, 259-263, 2001 
Geng, L., Schauer, A. J., Kunasek, S. A., Sofen, E. D., Erbland, J., Savarino, J., Allman, D. J., Sletten, R. S., and Alexander, B.: Analysis of oxygen-17 excess of nitrate and sulfate at submicromole levels using the pyrolysis method, Rapid Commun. Mass Sp., 27, 2411-2419, 2013.

Granger, J. and Sigman, D. M.: Removal of nitrite with sulfamic acid for nitrate $\mathrm{N}$ and $\mathrm{O}$ isotope analysis with the denitrifier method, Rapid Commun. Mass Sp., 23, 3753-3762, 2009.

Grilli, R., Legrand, M., Kukui, A., Mejean, G., Preunkert, S., and Romanini, D.: First investigations of $\mathrm{IO}, \mathrm{BrO}$, and $\mathrm{NO}_{2}$ summer atmospheric levels at a coastal East Antarctic site using modelocked cavity enhanced absorption spectroscopy, Geophys. Res. Lett., 40, 791-796, 2013

Hattori, S., Toyoda, A., Toyoda, S., Ishino S., Ueno, Y., and Yoshida, N.: Determination of the sulfur isotope ratio in carbonyl sulfide using gas chromatography/isotope ratio mass spectrometry on fragment ions ${ }^{32} \mathrm{~S}^{+},{ }^{33} \mathrm{~S}^{+}$, and ${ }^{34} \mathrm{~S}$, Anal. Chem., 87, 477-484, 2015.

Hill-Falkenthal, J., Priyadarshi, A., Savarino, J., and Thiemens, M.: Seasonal variations in ${ }^{35} \mathrm{~S}$ and $\Delta^{17} \mathrm{O}$ of sulfate aerosols on the Antarctic plateau, J. Geophys. Res. Atmos., 118, 9444-9455, 2013.

Holland, H. D., Lazar, B., and McCaffrey, M.: Evolution of atmosphere and oceans, Nature, 320, 27-33, 1986.

Holt, B. D., Cunningham, P. T., Engelkemeir, A. G., Graczyk, D. G., and Kumar, R.: Oxygen-18 study of nonaqueous-phase oxidation of sulfur dioxide, Atmos. Env., 17, 625-632, 1983.

Janssen, C. and Tuzson, B.: A diode laser spectrometer for symmetry selective detection of ozone isotopomers, Appl. Phys. B, 82, 487-494, 2006.

Jefferson, A., Tanner, D. J., Eisele, F. L., Davis, D. D., Chen, G., Crawford, J., Huey, J. W., Torres, A. L., and Berresheim, H.: $\mathrm{OH}$ photochemistry and methane sulfonic acid formation in the coastal Antarctic boundary layer, J. Geophys. Res., 103, 16471656, 1998.

Johnston, J. C. and Thiemens, M. H.: The isotopic compo- sition of tropospheric ozone in three environments, J. Geophys. Res. Atmos., 102, 25395-25404, 1997.

Jourdain, B. and Legrand, M.: Year-round records of bulk and sizesegregated aerosol composition and $\mathrm{HCl}$ and $\mathrm{HNO}_{3}$ levels in the Dumont d'Urville (coastal Antarctica) atmosphere: Implications for sea-salt aerosol fractionation in the winter and summer, J. Geophys. Res., 107, 4645, doi:10.1029/2002JD002471, 2002.

Kaleschke, L., Lupkes, C., Vihma, T., Haarpaintner, J., Bochert, A., Hartmann, J., and Heygster G.: SSM/I sea ice remote sensing for mesoscale ocean-atmosphere interaction analysis, Can. J. Remote Sens., 27, 526-537, 2001.

Konig-Langlo, G., King, J. C., and Pettre, P.: Climatology of the three coastal Antarctic stations Dumont d'Urville, Neumayer, and Halley, J. Geophys. Res., 103, 10935-10946, 1998.

Krankowsky, D., Bartecki, F., Klees, G. G., Mauersberger, K., Schellenbach, K., and Stehr, J.: Measurement of heavy isotope enrichment in tropospheric ozone, Geophys. Res. Lett., 22, 1713-1716, 1995.

Kukui, A., Legrand, M., Ancellet, G., Gros, V., Bekki, S., SardaEsteve, R., Loisil, R., and Preunkert, S.: Measurements of $\mathrm{OH}$ and $\mathrm{RO}_{2}$ radicals at the coastal Antarctic site of Dumont d'Urville (East Antarctica) in summer 2010-2011, J. Geophys. Res.-Atmos., 117, D12310, doi:10.1029/2012JD017614, 2012.
Kukui, A., Legrand, M., Preunkert, S., Frey, M. M., Loisil, R., Gil Roca, J., Jourdain, B., King, M. D., France, J. L., and Ancellet, G.: Measurements of $\mathrm{OH}$ and $\mathrm{RO}_{2}$ radicals at Dome C, East Antarctica, Atmos. Chem. Phys., 14, 12373-12392, doi:10.5194/acp-14-12373-2014, 2014.

Lee, C. C. W. and Thiemens, M. H.: The measurements of atmospheric sulfate from a coastal and high alpine region:A massindepent isotopic anomaly, J. Geophys. Res., 106, 17359-17373, 2001.

Legrand, M., Preunkert, S., Jourdain, B., Gallée, H., Goutail, F., Weller, R., and Savarino, J.: Year-round record of surface ozone at coastal (Dumont d'Urville) and inland (Concordia) sites in East Antarctica, J. Geophys. Res., 114, D20306, doi:10.1029/2008JD011667, 2009.

Legrand, M., Preunkert, S., Savarino, J., Frey, M. M., Kukui, A., Helmig, D., Jourdain, B., Jones, A. E., Weller, R., Brough, N., and Gallée, H.: Inter-annual variability of surface ozone at coastal (Dumont d'Urville, 2004-2014) and inland (Concordia, 2007-2014) sites in East Antarctica, Atmos. Chem. Phys., 16, 8053-8069, doi:10.5194/acp-16-8053-2016, 2016a.

Legrand, M., Yang, X., Preunkert, S., and Theys, N.: Year-round records of sea salt, gaseous, and particulate inorganic bromine in the atmospheric boundary layer at coastal (Dumont d'Urville) and central (Concordia) East Antarctic sites, J. Geophys. Res. Atmos., 121, 997-1023, doi:10.1002/2015JD024066, 2016b.

Li, X., Bao, H., Gan, Y., Zhou, A., and Liu, Y.: Multiple oxygen and sulfur isotope compositions of secondary atmospheric sulfate in a mega-city in central China, Atmos. Environ., 81, 591-599, 2013.

Matsuhisa, Y., Goldsmith, J. R., and Clayton, R. N.: Mechanisms of hydrothermal crystallization of quartz at $250^{\circ} \mathrm{C}$ and $15 \mathrm{kbar}$, Geochim. Cosmochim. Ac., 42, 173-182, 1978.

McCabe, J. R., Savarino, J., Alexander, B., Gong, S., and Thiemens, M. H.: Isotopic constraints on non-photochemical sulfate production in the Arctic winter, Geophys. Res. Lett., 33, L05810, doi:10.1029/2005GL025164, 2006.

Michalski, G., Scott, Z., Kabiling, M., and Thiemens, M. H.: First measurements and modeling of $\Delta^{17} \mathrm{O}$ in atmospheric nitrate, Geophys. Res. Lett., 30, 1870, doi:10.1029/2003GL017015, 2003.

Minikin, A., Legrand, M., Hall, J., Wagenbach, D., Kleefeld, C., Wolff, E., Pasteur, E. C., and Ducroz, F.: Sulfur-containing species (sulfate and methanesulfonate) in coastal Antarctic aerosol and precipitation, J. Geophys. Res., 103, 10975-10990, 1998.

Morin, S., Savarino, J., Bekki, S., Gong, S., and Bottenheim, J. W.: Signature of Arctic surface ozone depletion events in the isotope anomaly $\left(\Delta^{17} \mathrm{O}\right)$ of atmospheric nitrate, Atmos. Chem. Phys., 7, 1451-1469, doi:10.5194/acp-7-1451-2007, 2007.

Morin, S., Savarino, J., Frey, M. M., Yan, N., Bekki, S., Bottenheim, J. W., and Martins, J. M. F.: Tracing the origin and fate of $\mathrm{NO}_{x}$ in the Arctic atmosphere using stable isotopes in nitrate, Science, 322, 730-732, doi:10.1126/science.1161910, 2008.

Morin, S., Savarino, J., Frey, M. M., Domine, F., Jacobi, H. W., Kaleschke, L., and Martins, J. M. F.: Comprehensive isotopic composition of atmospheric nitrate in the Atlantic Ocean boundary layer from $65^{\circ} \mathrm{S}$ to $79^{\circ} \mathrm{N}$, J. Geophys. Res., 114, D05303, doi:10.1029/2008JD010696, 2009.

Morin, S., Sander, R., and Savarino, J.: Simulation of the diurnal variations of the oxygen isotope anomaly $\left(\Delta^{17} \mathrm{O}\right)$ of reac- 
tive atmospheric species, Atmos. Chem. Phys., 11, 3653-3671, doi:10.5194/acp-11-3653-2011, 2011.

Oduro, H., Van Alstyne, K. L., and Farquhar, J.: Sulfur isotope variability of oceanic DMSP generation and its contributions to marine biogenic sulfur emissions, P. Natl. Acad. Sci. USA, 109, 9012-9016, 2012.

Preunkert, S., Legrand, M., Jourdain, B., Moulin, C., Belviso, S., Kasamatsu, N., Fukuchi, M., and Hirawake, T.: Interannual variability of dimethylsulfide in air and seawater and its atmospheric oxidation by-products (methanesulfonate and sulfate) at Dumont d'Urville, coastal Antarctica (1999-2003), J. Geophys. Res., 112, D06306, doi:10.1029/2006JD007585, 2007.

Preunkert, S., Jourdain, B., Legrand, M., Udisti, R., Becagli, S., and Cerri, O.: Seasonality of sulfur species (sulfate, methanesulfonate and dimethyl sulfur) in Antarctica: inland versus coastal regions, J. Geophys. Res., 113, D15302, doi:10.1029/2008JD009937, 2008.

Santacesaria, V., MacKenzie, A. R., and Stefanutti, L.: A climatological study of polar stratospheric clouds (1989-1997) from LIDAR measurements over Dumont d'Urville (Antarctica), Tellus, 53B, 306-321, 2001.

Savarino, J. and Thiemens, M. H.: Analytical procedure to determine both $\delta^{18} \mathrm{O}$ and $\delta^{17} \mathrm{O}$ of $\mathrm{H}_{2} \mathrm{O}_{2}$ in natural water and first measurements, Atmos. Environ., 33, 3683-3690, 1999.

Savarino, J., Lee, C. C. W., and Thiemens, M. H.: Laboratory oxygen isotopic study of sulfur (IV) oxidation: Origin of the massindependent oxygen isotopic anomaly in atmospheric sulfates and sulfate mineral deposits on Earth, J. Geophys. Res., 105, 29079-29088. 2000.

Savarino, J., Alexander, B., Darmohusodo, V., and Thiemens, M. H.: Sulfur and oxygen isotope analysis of sulfate at micromole levels using a pyrolysis technique in a continuous flow system, Anal. Chem., 73, 4457-4462, 2001.

Savarino, J., Kaiser, J., Morin, S., Sigman, D. M., and Thiemens, M. H.: Nitrogen and oxygen isotopic constraints on the origin of atmospheric nitrate in coastal Antarctica, Atmos. Chem. Phys., 7, 1925-1945, doi:10.5194/acp-7-1925-2007, 2007.

Savarino, J., Bhattacharya, S. K., Morin, S., Baroni, M., and Doussin, J. F.: The $\mathrm{NO}+\mathrm{O}_{3}$ reaction: a triple oxygen isotope perspective on the reaction dynamics and atmospheric implications for the transfer of the ozone isotope anomaly, J. Chem. Phys., 128, 194303, doi:10.1063/1.2917581, 2008.

Savarino, J., Morin, S., Erbland, J., Grannec, F., Patey, M. D., Vicars, W., Alexander, B., and Achterberg, E. P.: Isotopic composition of atmospheric nitrate in a tropical marine boundary layer, P. Natl. Acad. Sci. USA, 110, 17668-17673, 2013.

Savarino, J., Vicars, W. C., Legrand, M., Preunkert, S., Jourdain, B., Frey, M. M., Kukui, A., Caillon, N., and Gil Roca, J.: Oxygen isotope mass balance of atmospheric nitrate at Dome C, East Antarctica, during the OPALE campaign, Atmos. Chem. Phys., 16, 2659-2673, doi:10.5194/acp-16-2659-2016, 2016.
Schauer, A. J., Kunasek, S. A., Sofen, E. D., Erbland, J., Savarino, J., Johnson, B. W., Amos, H. M., Shaheen, R., Abaunza, M., Jackson, T. L., Thiemens, M. H., and Alexander, B.: Oxygen isotope exchange with quartz during pyrolysis of silver sulfate and silver nitrate, Rapid Commun. Mass Sp., 26, 2151-2157, 2012.

Seinfeld, J. H. and Pandis, S. N.: Atmospheric Chemistry and Physics, 2nd edition, Wiley \& Sons, New York, USA, 2006.

Sofen, E. D., Alexander, B., and Kunasek, S. A.: The impact of anthropogenic emissions on atmospheric sulfate production pathways, oxidants, and ice core $\Delta^{17} \mathrm{O}\left(\mathrm{SO}_{4}^{2-}\right)$, Atmos. Chem. Phys., 11, 3565-3578, doi:10.5194/acp-11-3565-2011, 2011.

Stein, A. F., Draxler, R. R., Rolph, G. D., Stunder, B. J. B., Cohen, M. D., and Ngan, F.: NOAA's HYSPLIT atmospheric transport and dispersion modeling system, B. Am. Meteorol. Soc., 96, 2059-2077, doi:10.1175/BAMS-D-14-00110.1, 2015.

Troy, R. C. and Margerum, D. W.: Non-metal redox kinetics: Hypobromite and hypobromous acid reactions with iodide and with sulfite and the hydrolysis of bromosulfate, Inorg. Chem., 30, 3538-3543, doi:10.1021/ic00018a028, 1991.

Vicars, W. C. and Savarino, J.: Quantitative constraints on the ${ }^{17} \mathrm{O}$ excess $\left(\Delta^{17} \mathrm{O}\right)$ signature of surface ozone: ambient measurements from $50^{\circ} \mathrm{N}$ to $50^{\circ} \mathrm{S}$ using the nitrite-coated filter technique, Geochim. Cosmochim. Ac., 135, 270-287, 2014.

Vicars, W. C., Bhattacharya, S. K., Erbland, J., and Savarino, J.: Measurement of the ${ }^{17} \mathrm{O}$-excess $\left(\Delta^{17} \mathrm{O}\right)$ of tropospheric ozone using a nitrite-coated filter, Rapid Commun. Mass Sp., 26, 1219_ 1231, 2012.

von Glasow, R., Sander, R., Bott, A., and Crutzen, P. J.: Modeling halogen chemistry in the marine boundary layer. 2. Interactions with sulfur and the cloud-covered MBL, J. Geophys. Res., 107, 4323, 10.1029/2001JD000 943, 2002.

Vogt, R., Crutzen, P. J., and Sander, R.: A mechanism for halogen release from sea-salt aerosol in the remote marine boundary layer, Nature, 383, 327-330, doi:10.1038/383327a0, 1996.

Wagenbach, D., Ducroz, F., Mulvaney, R., Keck, L., Minikin, A., Legrand, M., Hall, J., and Wolff, E.: Sea-salt aerosol in coastal Antarctic regions, J. Geophys. Res., 103, 10961-10974, 1998.

Yiin, B. S. and Margerum, D. W.: Kinetics of Hydrolysis of the Chlorosulfate Ion, Inorg. Chem., 27, 1670-1672, doi:10.1021/ic00283a002, 1988.

Zatko, M., Geng, L., Alexander, B., Sofen, E., and Klein, K.: The impact of snow nitrate photolysis on boundary layer chemistry and the recycling and redistribution of reactive nitrogen across Antarctica and Greenland in a global chemical transport model, Atmos. Chem. Phys., 16, 2819-2842, doi:10.5194/acp-16-28192016, 2016. 